\title{
Impact of Apartment Tightness on Temperature Variability during a Fire
}

\author{
Jerzy Gałaj ${ }^{1, *(1)}$ and Damian Saleta ${ }^{2}(\mathbb{D}$ \\ 1 Institute of Safety Engineering, The Main School of Fire Service, 01-629 Warsaw, Poland \\ 2 Teaching Department, The Central School of State Fire Service, 42-200 Częstochowa, Poland; \\ damian.saleta@gmail.com \\ * Correspondence: jgalaj@sgsp.edu.pl; Tel.: +48-693-175-252
}

Received: 15 May 2020; Accepted: 24 June 2020; Published: 26 June 2020 updates

\begin{abstract}
Along with the thermal modernization process of old residential buildings, there has been a significant increase in the air tightness of apartments, which may contribute to the deterioration of the safety of users and rescue teams in a fire. The main goal of this study was to investigate the impact of the air tightness of an apartment on fire growth and temperature variability. In the work, an experimental method was applied. Two full-scale fire tests were carried out, one in a sealed apartment and the other in unsealed one. The temperature was measured by thirty-two thermocouples. Two thermal imaging and video cameras were also used to evaluate a temperature field as well as flame and smoke height. Based on the analysis, conclusions have been formulated. It is noteworthy that the highest temperatures and significant increase in pressure were obtained in a sealed apartment, but dangerous and critical conditions regarding firefighters' safety were achieved faster and persisted much longer in an unsealed one.
\end{abstract}

Keywords: real-scale fire tests; air tightness of residential apartment; fire environment; temperature variability during a fire; fire in apartment

\section{Introduction}

Due to increasing energy costs and requirements for thermal efficiency, many existing buildings in Poland are currently being improved with respect to the insulation properties of the enclosures as well as their air tightness. This process (often referred to as thermo-modernization) is beneficial in terms of the environmental performance of the residential buildings. However, the sealing of apartments can adversely affect the fire environment, e.g., toxicity. This article is a continuation of the topics discussed in the work [1], where, based on experimental research, it was shown that the sealing apartment results in an increase in the concentration of toxic gases in comparison with an unsealed apartment.

As it results from technical and construction regulations, the state of fire safety of a building is determined by the state of the environment in relation to people and by the state of the structure in relation to transferred loads [2]. The critical state of the fire environment is characterized by specific values of its parameters. They refer to thermal decomposition and combustion products, fire temperature and heat radiation power, oxygen concentration and visibility range. The impact of fire on the building structure is usually of a secondary nature, and its dynamic course mainly affects the internal environment of the building and the environment, e.g., the evacuation capabilities of users and the safety of firefighters [3].

Qualitative changes in the technology of construction and modernization of residential buildings caused that currently used building materials and equipment, in combination with modern building structures, can affect some parameters, e.g., temperature during fire in a sealed room. For example, this is indicated by studies carried out in Sweden described in [4]. The study of the impact of room 
tightness on fire development was presented in the paper basing on a 20-foot container used in the experiment.

The results of American research show that fires nowadays develop faster, more dynamically, emit more heat, are more toxic and go faster to the combustion controlled by ventilation [5]. This information is also confirmed in Polish literature [6,7]. Interesting real-scale fire experiments were carried out in 2006 in Glasgow, Scotland [8-10]. The dynamics of fire development in a 22-storey building were analyzed. Furthermore, the impact of various ventilation systems and the fire on the building structure was determined. Realistic fire development scenarios were divided into three groups. The first test concerned the uncontrolled development of fire, while the second test, controlled by ventilation, concerned rooms adapted for the living room/office. The third test concerned a series of tests to check smoke behavior in the stairwell.

Other interesting studies in real-scale were conducted on October 26th, 2011 in France. Fire tests were carried out in a single bedroom apartment $\left(9 \mathrm{~m}^{2}\right)$. Scientists studied, among others, which fire effect occurs first in a few simple scenarios using standard ISO 13571 to carry out tenability assessment [11]. Two series of tests were conducted, the first concerned a fire in a closed room, the second with an open door. In connection with the above, the ability to predict temperatures in a residential apartment is of great importance, especially for the possibility of evacuating their users and the safety of operations carried out by firefighters. For this purpose, a number of models are used to calculate the temperature in the rooms [12].

A comprehensive assessment of the air tightness of residential buildings was carried out in Finland [13]. In 2002-2009, the tightness of 170 single-family houses and 56 apartments was checked. The tests have shown very good levels of tightness thanks to many different combinations of insulation and barrier materials. In contrast, the effect of fire on the increase in pressure and ventilation flows was studied during a series of fire experiments in a typical Finnish apartment from the 1970s in the city of Kurikka. They were held in a flat on the first floor $\left(58.6 \mathrm{~m}^{2}\right)$ in a three-story building with a basement. The results obtained indicated a significant increase in pressure within a short period of time after the ignition of the fire [14].

It should be noted that the study of temperature and fire development in closed rooms was carried out in an international environment in the years 2006-2011 as part of the PRISME project, mainly in the nuclear area [15]. Extensive research conducted as part of the PRISME project in 2006-2011 (over 35 full-scale fire tests), concerned, among others, fire development in closed and ventilated large representative rooms for the nuclear area. They showed that in the event of a fire in the fire room, overpressures greater than 2500 Pa may occur in conjunction with a significant change in the operating conditions of the ventilation network [16].

In 2010, the Belgian Ministry of Interior funded a study about the fire hazards possibly associated with Passive Houses in comparison to traditional houses. The University of Mons and ISSeP used zone modelling for investigating how much the characteristics of a passive house such as air tightness, ventilation and thermal insulation could affect the fire development. A significant difference in pressure rise (due to thermal expansion of fumes) was observed because of the air tightness in the passive house. However, due to a lack of validation from experimental data on a large scale, the scientific monitoring committee of the project decided to not mention the potential problem that the forces of pressure could block the occupants during a certain period due to inwards-opening doors [17]. Five full-scale experiments were carried out: two in 2016 by Berthelot and three in 2017 by Piret-Gerard. Another experiment related to the increase in pressure and the heat release rate during fires in passive houses was performed by Caravita on 19 December 2017 for needs of MA thesis at the University of Bologna. The research from 2016 and 2017 was carried out on a specially designed hermetic facility that had the same internal dimension as a 40 -foot transport container. The experiments carried out indicate the problems associated with overpressure in passive houses in the event of a fire [18].

The purpose of the research, the results of which are presented in this article, was to determine the impact of air tightness of residential apartments on fire development and selected parameters of 
the fire environment, such as temperature, the height of the flame and smoke-free space and pressure in the context of user and firefighter's safety.

\section{Experimental Setup}

The experiments were conducted in a residential five-story building situated in Bytom (Silesian District, Poland), which was intended for demolition. It was built in 1976, made in the technology of a prefabricated reinforced concrete slabs (after removing the facade slabs, it turned out that the building was additionally made of aerated concrete blocks, i.e., gray cellular concrete). The pictures of the building before and after removing the facade panels are presented in Figure 1a,b, respectively.

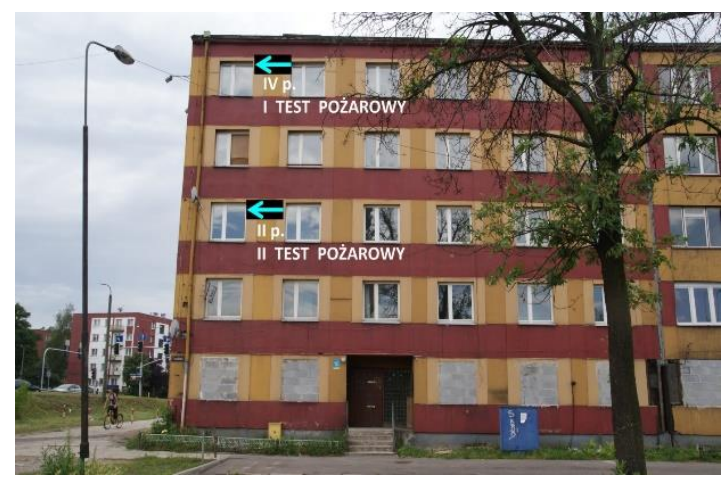

(a)

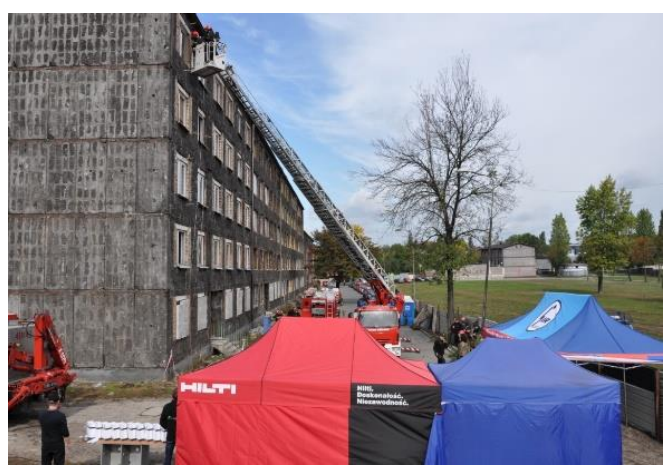

(b)

Figure 1. Pictures of a residential building at Pocztowa Str. 15 in Bytom from the north, scheduled for fire tests: (a) before the removal of facade panels containing asbestos (July 2012); (b) on the day of the experiment (20 September 2012).

Two full-scale fire tests were conducted in the building, where two fire scenarios were assumed, for:

1. A sealed apartment No. 19 (poorly ventilated) located on the fourth floor with an area of $36.56 \mathrm{~m}^{2}$ (cubic capacity $91.4 \mathrm{~m}^{3}$ ). In the rest of the article, it will be designated by B1 (the first test).

2. An unsealed apartment No. 11 located on the second floor with an area of $37.59 \mathrm{~m}^{2}$ (cubic capacity of $93.9 \mathrm{~m}^{3}$ ). In the rest of this article, it will be designated by B2 (the second test).

The room in both apartments, in which the fire source was located, was the same area of $15.41 \mathrm{~m}^{2}$. In the sealed apartment, the following configuration of ventilation openings was used: all windows and doors to the apartment were closed, all interior doors were fully open, the vent in the kitchen with dimensions of $14 \times 14 \mathrm{~cm}$ was open, while such vent were closed in the bathroom. In the unsealed apartment, the same configuration of ventilation openings was used, except for one window from the north whose one wing with dimensions $915 \times 1425 \mathrm{~cm}$ was tilted $20 \mathrm{~cm}$ wide. During both tests, the wind was blowing from the west, but its speed was higher during the fire test in the unsealed apartment $(4.5 \mathrm{~m} / \mathrm{s})$ than the sealed one $(1.5 \mathrm{~m} / \mathrm{s})$. In both apartments, the furniture and their settings were identical. They were made to order from the same materials and according to the same pattern (three couches and three armchairs). Each apartment was equipped with the following combustible materials: couch, two armchairs, wall unit, table, blanket, bedding set, tablecloth, pair of trousers, sweater, curtain, and carpet covering $7.5 \mathrm{~m}^{2}$. Due to the fact that during the tests the fire was located and no flashover occurred in the entire fire zone, in accordance with the Polish standard PN-B-02852:2001, the actual surface on which the combustible material was located was used to determine the fire load density. It was about $306 \mathrm{MJ} / \mathrm{m}^{2}$ for this area (approximately $9 \mathrm{~m}^{2}$ ) and on average $179 \mathrm{MJ} / \mathrm{m}^{2}$ for the entire room area with dimensions $520 \times 274 \times 255 \mathrm{~cm}$ (approximately $15 \mathrm{~m}^{2}$ ). Pictures of two rooms before fire tests are shown in Figure 2 (sealed in Figure 2a and unsealed in Figure 2b). Measuring stations for the current registration of results during fire tests were located in rooms directly 
below the examined apartments, i.e., on the third floor during the first test (B1) and on the first floor during the second test (B2).

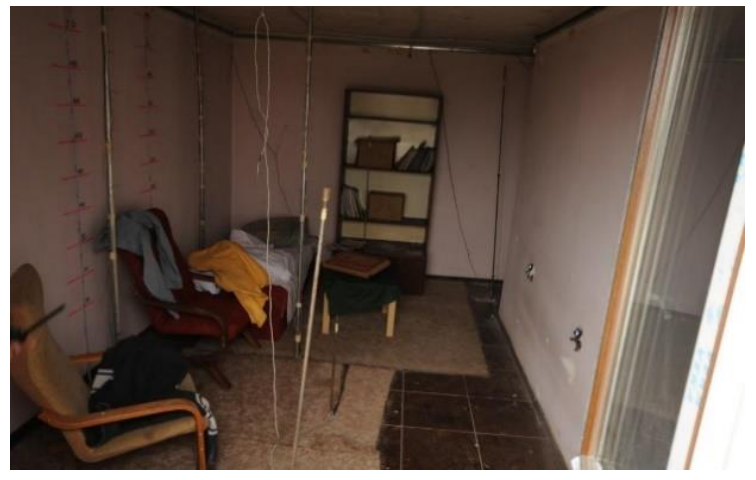

(a)

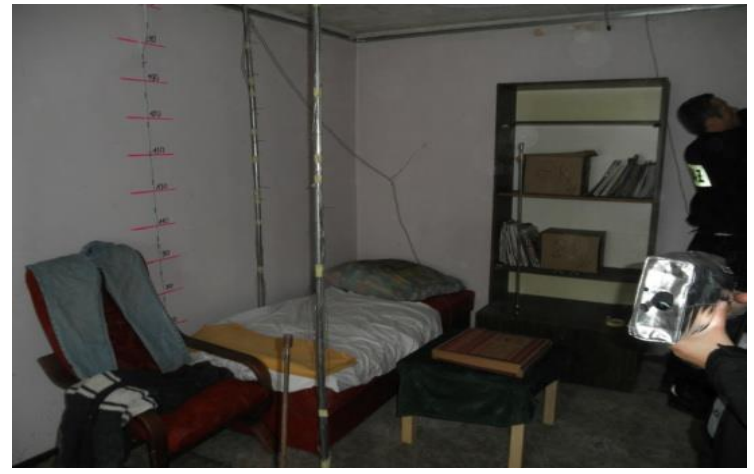

(c)

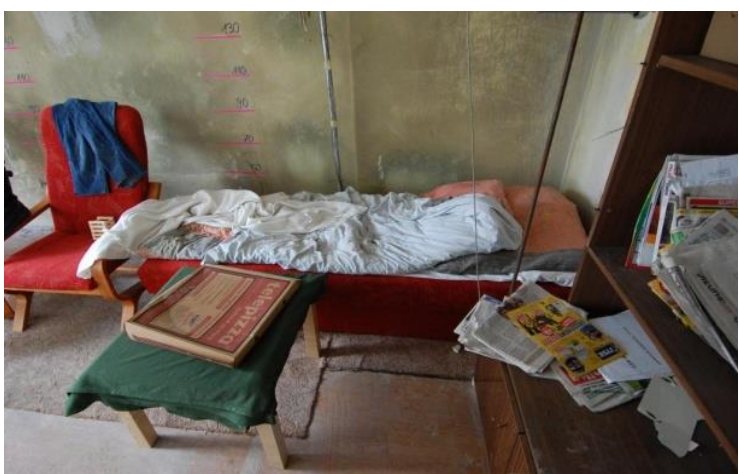

(b)

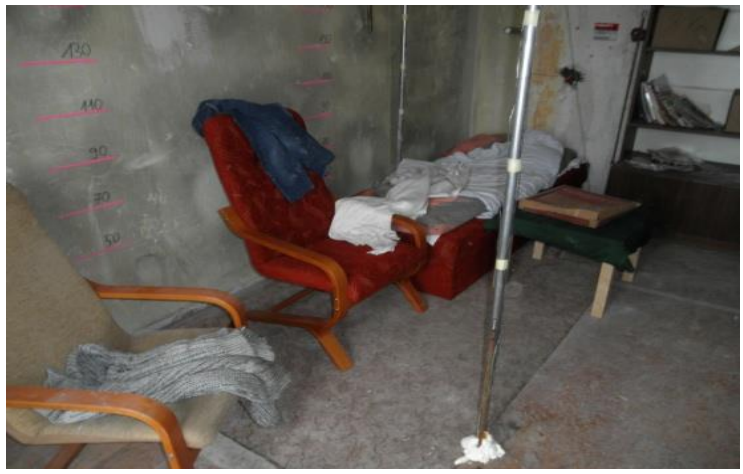

(d)

Figure 2. Pictures of rooms where fire tests were carried out: (a) sealed; (b) unsealed; (c) sealed; (d) unsealed.

The ignition sources and their location (the seat of the armchair next to the couch) during full scale fire tests were identical for both apartments. They consist of two elements:

1. Spruce wood pile made in accordance with British BS5852 "wood crib 7" (combustion heat $2110 \mathrm{~kJ}$, flame height $345-490 \mathrm{~mm}$, heat flux $25 \mathrm{~kW} / \mathrm{m}^{2}$, fuel supply indicator $32 \mathrm{~g} \mathrm{~min}^{-1}, 90 \%$ weight loss, time $375 \mathrm{~s}$, burning time $390 \mathrm{~s}$ ). There was also a blanket and denim jeans on the armchair

2. ROTHENBERGER soldering torch with a disposable container with the MULTIGAS 300 propane/ butane gas mixture ( $35 \%$ propane, $65 \%$ butane). Technical data: flame temperature up to $1900{ }^{\circ} \mathrm{C}$. Container $600 \mathrm{~mL} / 338 \mathrm{~g}$, No.3.5510, designed for all soldering torches and ROTHENBERGER instruments equipped with a connection made according to DIN EN 417. The containers are filled with purified gas. Gas is harmless to the earth's ozone layer, FCKW-free, TÜV certified

The picture of the place and source of ignition are shown in Figure 3. 


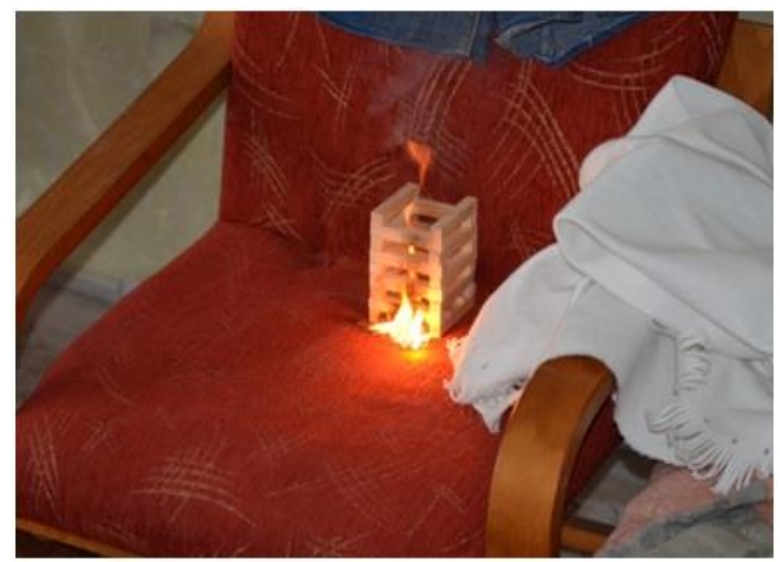

Figure 3. Picture of the place and source of ignition.

\section{Experimental Methods}

The following measuring apparatus was used to measure the distribution and temperature field during the two full-scale fire tests:

1. Thirty-two " $\mathrm{K}$ "-type thermocouples (NiCr-NiAl) with a measuring range from -200 to $+1200{ }^{\circ} \mathrm{C}$ with a mantle sensor. They are mounted on the thermocouple trees marked from t6 to t9, respectively.

2. Three thermocouples type " $\mathrm{K}$ " with a wire sensor. They are marked from $\mathrm{T} 1$ to $\mathrm{T} 3$, respectively. The accuracy of the " $\mathrm{K}$ "-type thermocouples was $1.5^{\circ} \mathrm{C}$ in the range from -200 to $375^{\circ} \mathrm{C}$ and $0.4 \%$ in the range from 375 to $1200^{\circ} \mathrm{C}$.

3. MPI-L-16-4-16 analog signal multiplexer with recording function and accuracy in class 1 shown in Figure $4 a$.

4. Dräger UCF 7000 thermal imaging camera shown in Figure 5a. Temperature measurement in the range from -40 to $1000{ }^{\circ} \mathrm{C}$. Resolution $160 \times 120$ pixels. Thermal sensitivity $0.035{ }^{\circ} \mathrm{C}$. Tightness class IP 67 [19].

5. Hornet $320 \mathrm{~B}$ thermal imaging camera shown in Figure $5 \mathrm{~b}$. Temperature measurement in the range from -20 to $590{ }^{\circ} \mathrm{C}$. Spectrum range $7-14 \mu \mathrm{m}$. Resolution $320 \times 240$ pixels. Thermal sensitivity less than $16 \mathrm{mK}$ at f/1.6. Tightness class IP 67 [20].

6. DPT 01 recorder with LCD display shown in Figure $4 \mathrm{~b}$. The technical data of it are as follows: $4.20 \mathrm{~mA}$ current output and measuring range $\pm 100 \mathrm{~Pa}$. Measurement accuracy $\pm 1.5 \mathrm{~Pa}$. The degree of protection IP 54. Equipped with a pressure probe with an aPVC hose [21].

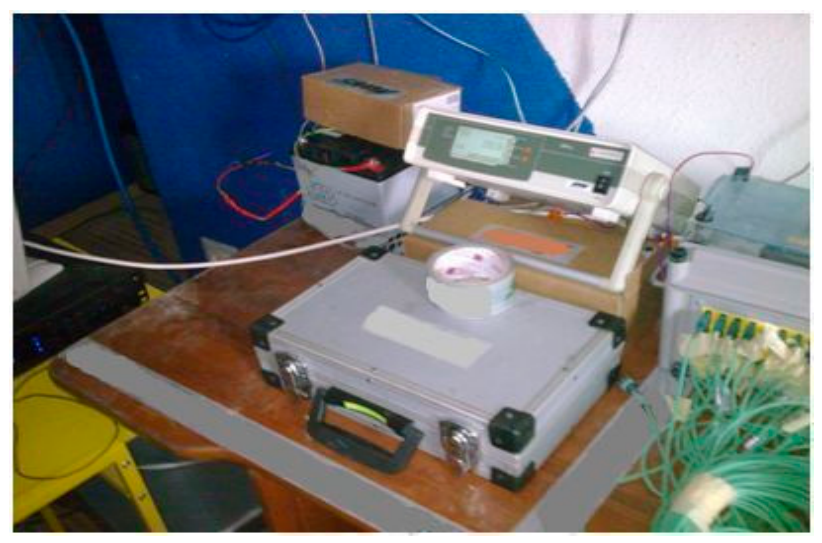

(a)

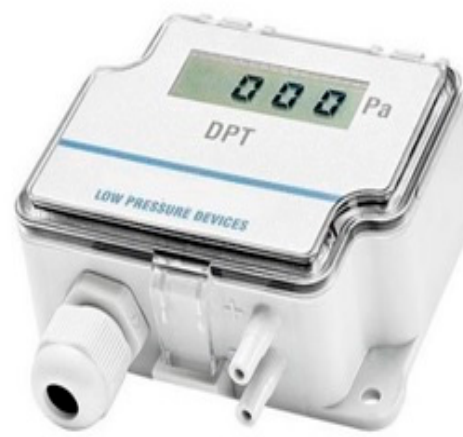

(b)

Figure 4. Pictures of: (a) analog signal multiplexer MPI-L-16-4-16; (b) recorder DPT 01. 


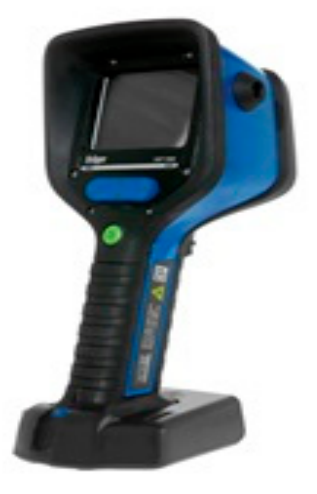

(a)

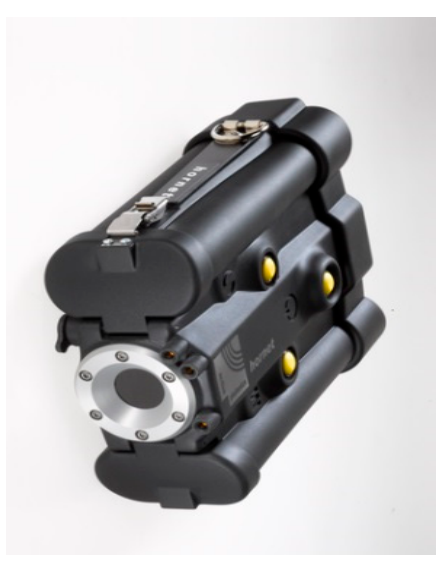

(b)

Figure 5. Pictures of two thermal imaging cameras: (a) Dräger UCF 7000; (b) Hornet 320 B.

In order to measure the temperature inside room 1 during a fire, four thermocouple trees: t6 (near the corner), $\mathrm{t} 7$ (between the armchairs near the wall), $\mathrm{t} 8$ (between the armchair and the couch in front of them) and $\mathrm{t} 9$ (behind the couch near the wall) were installed in it. They were mounted at the following heights measured from the floor in cm: 105, 135, 165, 185, 205, 225, 235 and 245. Due to damage of thermocouples on the $t 7$ tree during the first test (B1), the $t 7$ tree was removed and the position of the $t 8$ tree was slightly changed (see Figures 6 and 7) during the second test (B2). In addition, three single thermocouples (T1, T2 and T3) were placed inside the room (Figure 8a). The thermocouple T1 was mounted at a height of $200 \mathrm{~cm}$ near the corridor, T2 at a height of $180 \mathrm{~cm}$ over the coach and T3 at a height of $150 \mathrm{~cm}$ in front of the armchair. The pressure measuring point was installed near the corner adjacent to the wall with the window at a height of $190 \mathrm{~cm}$. The arrangements of furniture, thermocouples tree, single thermocouples, pressure measuring point (marked by the end of blue line illustrating the wires connecting this point with the recorder) and cameras in the room for sealed and unsealed apartments are shown in Figures 6 and 7, respectively.

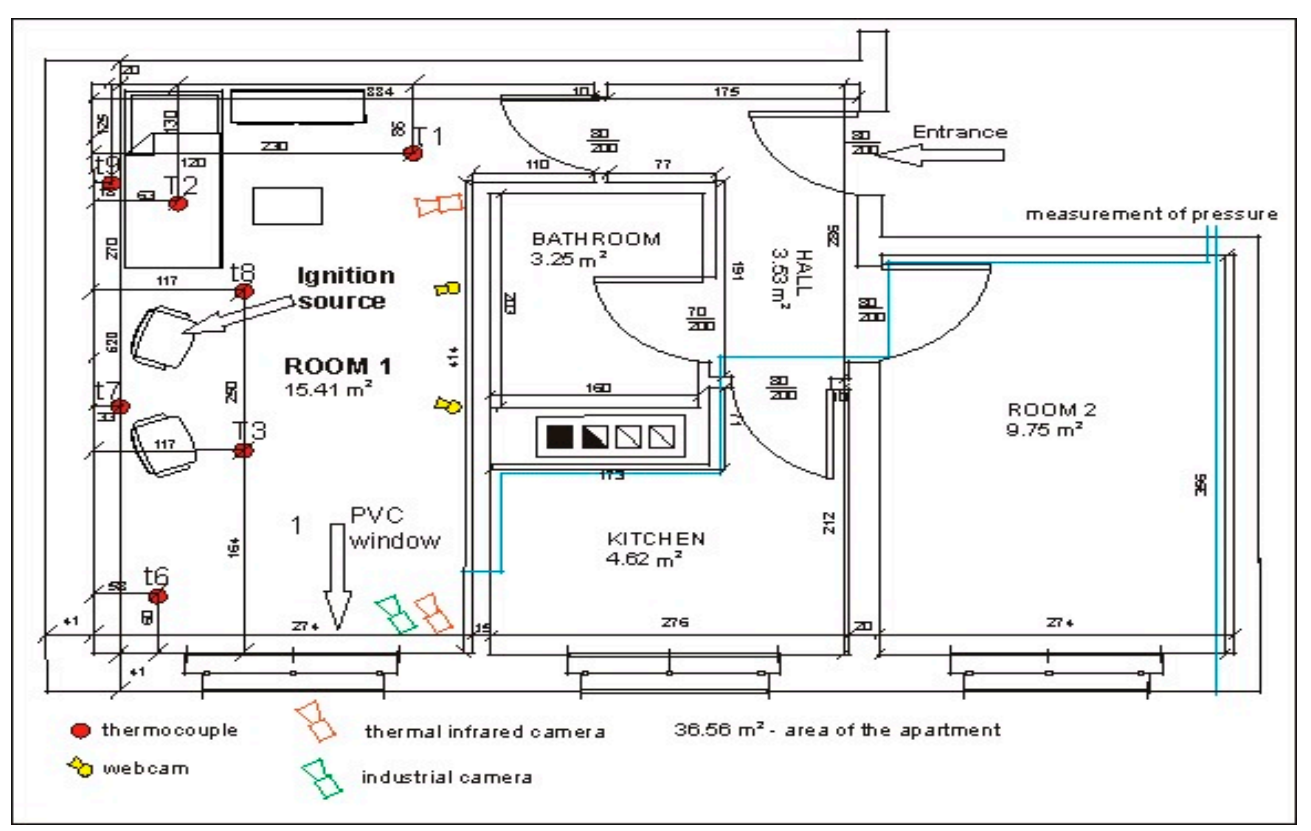

Figure 6. Arrangement of furniture, metal probes, thermocouples tree, thermocouples and cameras in the sealed room. 


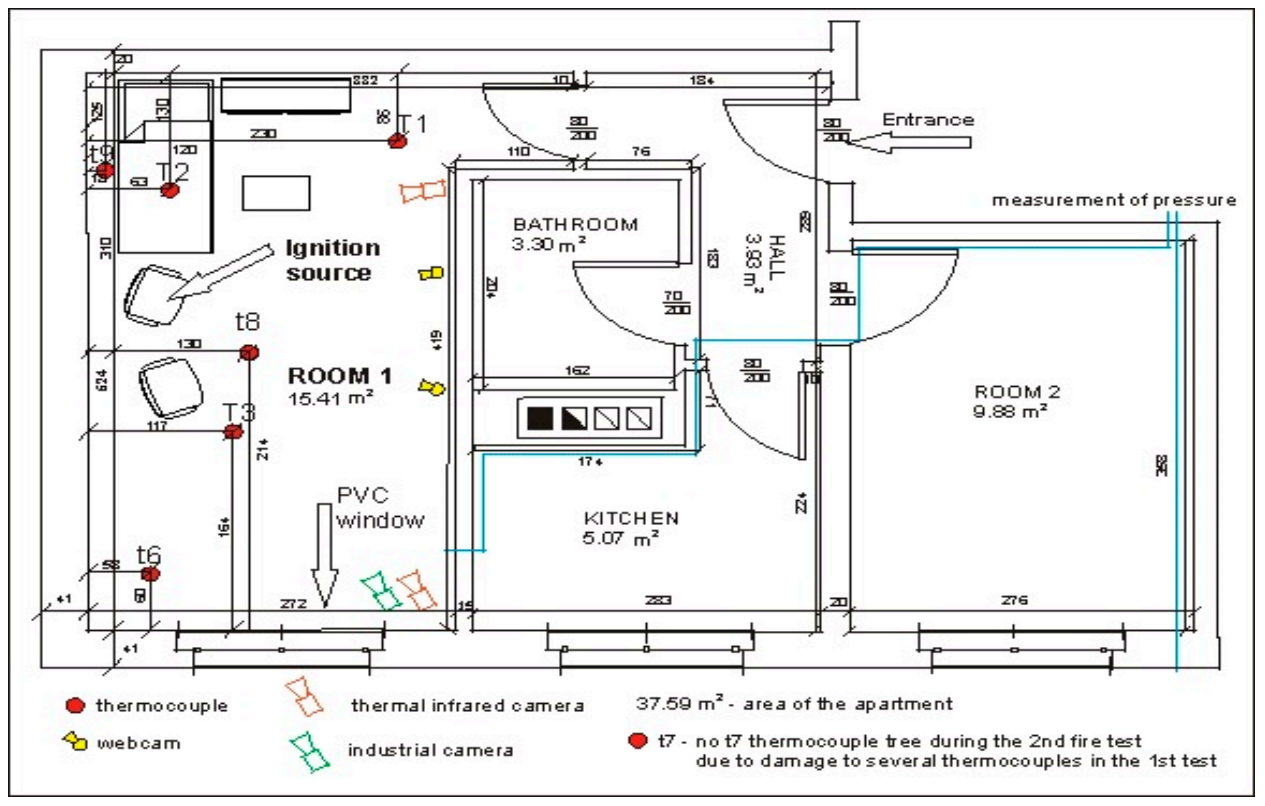

Figure 7. Arrangement of metal probes, thermocouples tree, thermocouples and cameras in the unsealed room.

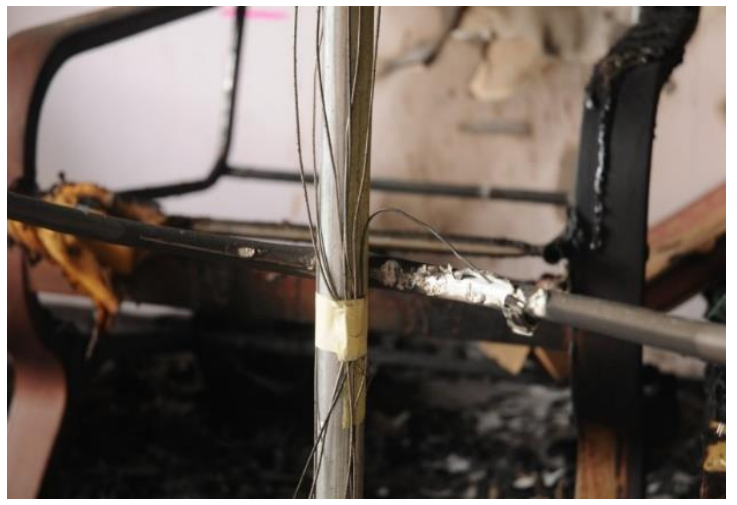

(a)

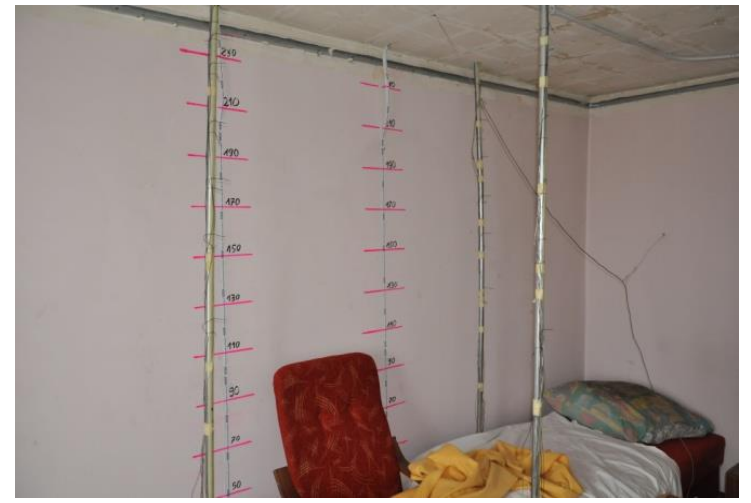

(b)

Figure 8. Pictures of: (a) a thermocouple T3 placed by the armchair after fire test; (b) a scale with height levels on the wall.

Table 1 lists the thermocouple designations on four trees $t 6, t 7, t 8$ and $t 9$ located inside the room.

Table 1. Thermocouples markings.

\begin{tabular}{cccccc}
\hline & \multirow{2}{*}{$\begin{array}{c}\text { Height Measured } \\
\text { No. }\end{array}$} & \multicolumn{4}{c}{ Thermocouple Tree } \\
\cline { 3 - 6 } & 105 & $\mathbf{t} 6$ & $\mathbf{t} 7$ & $\mathbf{t} 8$ & $\mathbf{t 9}$ \\
\hline 1 & 135 & $\mathrm{t} 6.1$ & $\mathrm{t} 7.1$ & $\mathrm{t} 8.1$ & $\mathrm{t} 9.1$ \\
2 & 165 & $\mathrm{t} 6.3$ & $\mathrm{t} 7.2$ & $\mathrm{t} 8.2$ & $\mathrm{t} 9.2$ \\
3 & 185 & $\mathrm{t} 6.4$ & $\mathrm{t} 7.4$ & $\mathrm{t} 8.3$ & $\mathrm{t} 9.3$ \\
4 & 205 & $\mathrm{t} 6.5$ & $\mathrm{t} 7.5$ & $\mathrm{t} 8.5$ & $\mathrm{t} 9.4$ \\
5 & 225 & $\mathrm{t} 6.6$ & $\mathrm{t} 7.6$ & $\mathrm{t} 8.6$ & $\mathrm{t} 9.6$ \\
6 & 235 & $\mathrm{t} 6.7$ & $\mathrm{t} 7.7$ & $\mathrm{t} 8.7$ & $\mathrm{t} 9.7$ \\
7 & 245 & $\mathrm{t} 6.8$ & $\mathrm{t} 7.8$ & $\mathrm{t} 8.8$ & $\mathrm{t} 9.8$ \\
8 & & & & &
\end{tabular}


The simultaneous recording of temperature in thirty-five (sealed apartment) or twenty-seven (unsealed apartment) measuring tracks took place every $8 \mathrm{~s}$.

The research procedure consisted of the following activities carried out in the listed in order:

1. Preparation of the test apparatus for fire tests:

- Checking and testing of a computer program for recording and reading temperatures

- Connection, calibration, and checking the operation of measuring sensors, among others thermocouples, recorders, infrared cameras, smoke detectors or fire alarm system

- Measurement of initial ambient conditions (wind speed, pressure differences between the building and the environment, and between the staircase and the dwelling, indoor and outdoor air temperature)

- $\quad$ Preliminary flammability test of the wooden pile made for the requirements of Wood Crib 7 according to the British BS 5852 standard to confirm the height of the flame (in the range $34.5-49 \mathrm{~cm}$ ) and the time of its complete burning (approximately $6.5 \mathrm{~min}$ )

2. Setting an 8-s time step when taking measurements of temperature.

3. Setting fire to the wooden stack placed on the armchair and simultaneously starting the recording of measurements. The possibility of the emergency termination of tests is provided in the event of a situation threatening the safety of the persons carrying out the measurements and who are in the room located under the fire.

4. Completion of the test in a sealed apartment $30 \mathrm{~min}$ after ignition and switching off part of the measuring apparatus. The measurement of the temperatures at T1, T2, and T3 continued for $20 \mathrm{~min}$ from the end of the test and planned intervention of firefighters (the place of fire was extinguished and a window in the room was opened to smoke the apartment).

5. Firemen putting out the fire and opening a window in the room to smoke the apartment.

6. Checking the building's safety by a firefighter in charge of Rescue Activities and diagnostics of building structural damage to the building by the District Building Supervision Inspector.

7. Carrying out the second test in the unsealed apartment according to the procedure described in points 1-6.

\section{Experimental Results}

Air tightness measurements for a sealed (B1) and unsealed (B2) apartments according to standard PN-EN ISO 9972: 2015-10 (Blower Door Test) were conducted by ADM Thermo Company, 43-180 Orzesze, Poland. The obtained results are shown in Table 2. Comparing the values given in the table for a sealed room with the recommendations in force in various countries of our climate zone, which can be found, e.g., in [22], it can be stated that the measured air exchange $\left(5.7 \mathrm{~m}^{3} /\left(\mathrm{h} \cdot \mathrm{m}^{2}\right)\right)$ in most cases does not exceed the maximum recommended level (e.g., $7.8 \mathrm{~m}^{3} /\left(\mathrm{h} \cdot \mathrm{m}^{2}\right)$ in Germany or $10 \mathrm{~m}^{3} /\left(\mathrm{h} \cdot \mathrm{m}^{2}\right)$ in Great Britain).

Table 2. Values of air flow, number of air changes, air permeability and unit leakage stream measured during two analyzed tests B1 and B2.

\begin{tabular}{cccccc}
\hline \multirow{2}{*}{ Parameter } & \multirow{2}{*}{ Notation } & \multirow{2}{*}{ Unit } & \multicolumn{2}{c}{ Results } & Uncertainty \\
\cline { 4 - 6 } & & & B1 & B2 & B1 and B2 \\
\hline Air flow & $\mathrm{V}_{50}$ & $\mathrm{~m}^{3} / \mathrm{h}$ & 549 & 1098 & $\pm 7 \%$ \\
\hline Number of air changes & $\mathrm{n}_{50}$ & $\mathrm{~h}^{-1}$ & 5.8 & 11.6 & $\pm 9 \%$ \\
\hline Air permeability & $\mathrm{q}_{50}$ & $\mathrm{~m}^{3} /\left(\mathrm{h} \cdot \mathrm{m}^{2}\right)$ & 5.7 & 11.3 & $\pm 9 \%$ \\
\hline Unit leakage stream & $\mathrm{w}_{50}$ & $\mathrm{~m}^{3} /\left(\mathrm{h} \cdot \mathrm{m}^{2}\right)$ & 14.5 & 28.9 & $\pm 9 \%$ \\
\hline
\end{tabular}


The pressure distributions measured by recorder DPT 01 for the sealed (B1) and unsealed apartments (B2) are shown in Figure 9a,b, respectively. The ambient pressure was on the day of testing $\mathrm{p}=987 \mathrm{hPa}$. Before testing, the overpressure in the fire-covered room against atmospheric pressure and the pressure difference between the fire zone and the staircase were checked. Both measurements indicated level " $0 \mathrm{~Pa}$ ". According to measurement data, typical staircase airflow resistance per single floor is in the range 3-5 Pa for the class B system of EN 12101-6 European Standard.

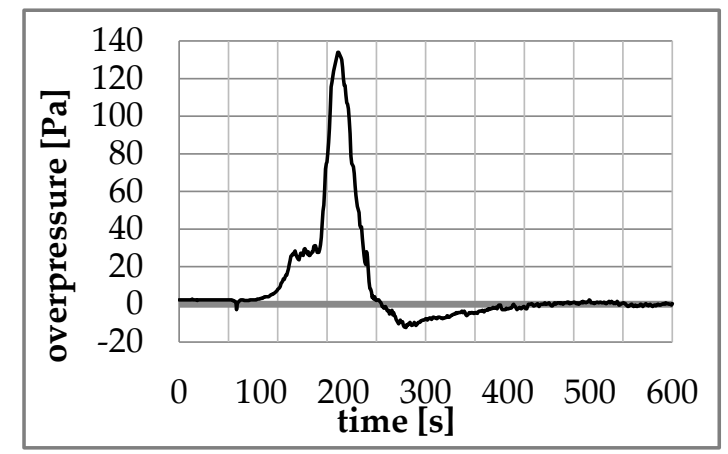

(a)

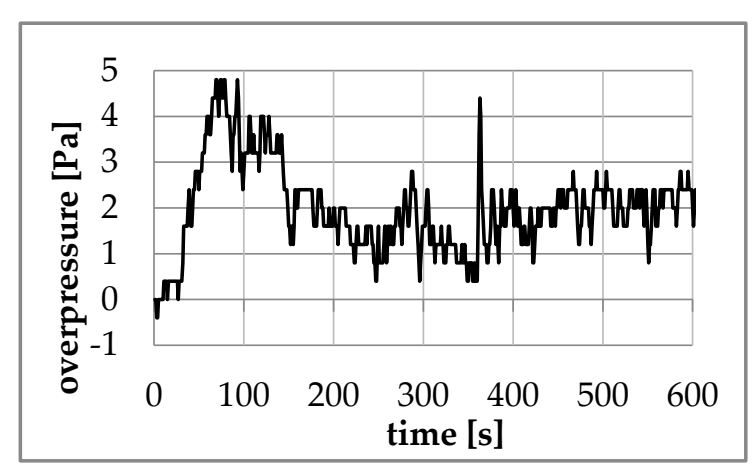

(b)

Figure 9. Overpressure curves obtained during test in: (a) sealed apartment (B1); (b) unsealed apartment (B2).

The maximum and minimum pressure values and the time when they were obtained during the $\mathrm{B} 1$ and $\mathrm{B} 2$ tests are presented in Table 3.

Table 3. Maximum and minimum values of pressure obtained during tests B1 and B2.

\begin{tabular}{ccccc}
\hline \multirow{2}{*}{ Parameter } & \multicolumn{2}{c}{ Pressure (Pa) } & \multicolumn{2}{c}{ Time (s) } \\
\cline { 2 - 5 } & B1 & B2 & B1 & B2 \\
\hline Maximum & 134.0 & 4.8 & 193 & 69 \\
Minimum & -12.4 & 0.4 & 276 & 248 \\
\hline
\end{tabular}

Based on observations and images obtained from thermal imaging cameras and video, the descriptions of fire growth separately for sealed and unsealed apartments are included in Tables 4 and 5, respectively (the times are counted from ignition).

In order to compare temperatures measured at different heights and in different places of the room during the first fire test (B1) in a sealed apartment and the second fire test (B2) in an unsealed one, temperature changes over time are shown in Figures 10-13. Temperature measured by thermocouples on trees $t 6, t 8$ and $t 9$ (the measuring path of the $t 7$ thermocouple tree was damaged during the second test) are shown at three selected heights: $105 \mathrm{~cm}$ (level above the head of a leaning man), $185 \mathrm{~cm}$ (level above the head of a standing or walking man) and $245 \mathrm{~cm}$ (ceiling zone). Figure 13 shows the temperature measured by thermocouples T1, T2 and T3. The solid line shows the curve obtained during the first fire test (B1) and the dashed line the curve obtained during the second fire test (B2). To be able to analyze the characteristic quantities associated with the measured temperatures, Tables 6-9 summarize the maximum and minimum temperatures and the times to reach them. To illustrate the fire history during performed tests frames from the movie recorded with thermal imaging camera for a few selected times are shown in Figures 14-16. To assess the temperature values measured during tests B1 and B2 for a critical value of $60{ }^{\circ} \mathrm{C}$ at an altitude of $1.85 \mathrm{~m}$ adopted in accordance with [23], the times of exceeding it during either temperature increase (time 1) or decrease (time 2) are given in Table 10 (times are counted from the moment of ignition). The values of temperature and height of the smoke layer for selected times of fire during two analyzed tests B1 and B2 are collected in Table 11. 
They were estimated using a scale applied on the wall (see Figure 8b), thermograms prepared by a thermal imaging camera and recordings from a VHS camera placed in the hallway.

Table 4. Description of fire growth during test in the sealed apartment.

\begin{tabular}{|c|c|c|}
\hline From (s) & To (s) & Description \\
\hline 0 & 24 & $\begin{array}{l}\text { A gas burner was used to initiate a fire in a sealed apartment, with which a pile } \\
\text { of spruce wood was placed on a chair near the couch. The ignition time was } 5 \mathrm{~s} \text {. }\end{array}$ \\
\hline 24 & 49 & $\begin{array}{l}\text { The fire growth phase began. There was a moment of heating, thermal } \\
\text { decomposition and ignition of materials around the pile (part of the seat and } \\
\text { back of the armchair). The flame height was in the range from } 34 \mathrm{~cm} \text { to } 49 \mathrm{~cm} \text {. }\end{array}$ \\
\hline 49 & 99 & $\begin{array}{l}\text { The accelerated thermal decomposition and combustion of the armchair occurred. } \\
\text { Flame propagation took place in the direction of convective flow over the surface } \\
\text { of the burning armchair. The flame reached a height of } 130 \mathrm{~cm} \text { above the floor. }\end{array}$ \\
\hline 99 & 124 & $\begin{array}{l}\text { The armchair with ignition source burned out. The smoke surface in the ceiling } \\
\text { increased. The flame reaches } 210 \mathrm{~cm} \text { above the floor. }\end{array}$ \\
\hline 124 & 199 & $\begin{array}{l}\text { The fire spread to the couch and the temperature increases steadily. In this time } \\
\text { period (approximately after } 180 \mathrm{~s} \text { from ignition) the fire passed from the } \\
\text { fuel-controlled phase to the ventilation-controlled phase. The smoke layer lowers } \\
\text { from the ceiling level to a height of about } 150 \mathrm{~cm} \text {. }\end{array}$ \\
\hline 199 & 224 & $\begin{array}{l}\text { A decrease in combustion intensity was observed. The surface of the convection } \\
\text { column of fire has decreased. The smoke increased and the height of the } \\
\text { diffusion flame decreased to a level about } 150 \mathrm{~cm} \text { above the floor. The smoke } \\
\text { layer remained at a level of about } 40 \mathrm{~cm} \text { from the floor. }\end{array}$ \\
\hline 224 & 250 & $\begin{array}{l}\text { There was a further decrease in the intensity of flame combustion caused an } \\
\text { increase in the evolution of toxic combustion products and combustible fire gases. } \\
\text { Only part of the couch surface was affected by the fire. A low flame } \\
\text { approximately } 70 \mathrm{~cm} \text { high was observed on the couch surface. The smoke layer } \\
\text { remained at a level of approximately } 40 \mathrm{~cm} \text { above the floor. }\end{array}$ \\
\hline 250 & 275 & $\begin{array}{l}\text { A systematic decrease in the rate of heat released, reduction in the combustion } \\
\text { area and an increase in intensity of the release of incomplete combustion } \\
\text { products. The smoke layer was still around } 40 \mathrm{~cm} \text { above the floor. }\end{array}$ \\
\hline 275 & 400 & $\begin{array}{l}\text { The temperature dropped to } 85^{\circ} \mathrm{C} \text {. The smoke layer increased to approximately } \\
50 \mathrm{~cm} \text { above the floor. }\end{array}$ \\
\hline 400 & 1200 & $\begin{array}{l}\text { The flame was maintained at a height of approximately } 70 \mathrm{~cm} \text { in the central part } \\
\text { of the couch and the continuous release of smoke from the burned part of the } \\
\text { mattress was observed. The smoke layer did not change and remained at a level } \\
\text { of approximately } 50 \mathrm{~cm} \text { above the floor. The average temperature was } \\
\text { approximately of } 50{ }^{\circ} \mathrm{C} \text {. }\end{array}$ \\
\hline 1200 & 1800 & $\begin{array}{l}\text { Only single tongues of fire were found on the couch surface at a height of } \\
\text { approximately } 40 \mathrm{~cm} \text { above the floor. The temperature displayed on the thermal } \\
\text { imager was } 34^{\circ} \mathrm{C} \text {. The smoke layer was approximately of } 70 \mathrm{~cm} \text { above the floor. }\end{array}$ \\
\hline
\end{tabular}


Table 5. Description of fire growth during test in the unsealed apartment.

\begin{tabular}{|c|c|c|}
\hline From (s) & To (s) & Description \\
\hline 0 & 30 & $\begin{array}{l}\text { A gas burner was used to initiate a fire in a sealed apartment, with which a pile of } \\
\text { spruce wood was placed on an armchair near the couch. The ignition time was } 4 \mathrm{~s} \text {. }\end{array}$ \\
\hline 30 & 60 & $\begin{array}{l}\text { The initial phase of fire growth, heating and thermal decomposition of the } \\
\text { surroundings of the fire source occurred (part of the seat and back of the armchair). } \\
\text { The flame height was approximately } 50 \mathrm{~cm} \text { above the floor. }\end{array}$ \\
\hline 60 & 90 & $\begin{array}{l}\text { There was still local combustion. The fire developed more slowly at this stage than } \\
\text { during the first test. A smoky layer began to form in the upper part of the room. } \\
\text { There was a systematic increase in flame height. }\end{array}$ \\
\hline 90 & 120 & $\begin{array}{l}\text { The flame was approximately at a height of } 110 \mathrm{~cm} \text { above the floor. From this } \\
\text { moment faster burning and increase of fire development were observed. }\end{array}$ \\
\hline 120 & 150 & $\begin{array}{l}\text { The rapid growth of the convective column and faster heat transfer generated by the } \\
\text { flame (heat radiation flux density), which reached the ceiling were observed. } \\
\text { The temperature on the thermal imager increased slightly to } 27^{\circ} \mathrm{C} \text {. A layer of smoke } \\
\text { was formed. }\end{array}$ \\
\hline 150 & 180 & $\begin{array}{l}\text { The combustion zone increased. The fire spread to the couch, where rapid heating } \\
\text { and thermal decomposition of the entire surface of the material covering the mattress } \\
\text { was observed. Inflammation of the carpet between the armchair and the couch was } \\
\text { also noticed. In the ceiling zone, the density of the smoke layer increased as a result } \\
\text { of the extraction of pyrolysis products running deep into the mattress } \\
\text { polyurethane foam. }\end{array}$ \\
\hline 180 & 270 & $\begin{array}{l}\text { The temperature increased rapidly. The rapid spread of flame over the entire surface } \\
\text { of the couch was observed. The flame height reached the ceiling and collapsed along } \\
\text { the ceiling for a length of approximately } 80 \mathrm{~cm} \text { (couch width). The smoke layer } \\
\text { reached up to approximately } 130 \mathrm{~cm} \text { above the floor. }\end{array}$ \\
\hline 270 & 720 & $\begin{array}{l}\text { The flame height lowered to a level of } 150 \mathrm{~cm} \text { above the floor, due to the intake of } \\
\text { cold air through the window and heat loss on the ceiling surface (high thermal } \\
\text { conductivity). The temperature indicated by the thermal imaging camera dropped } \\
\text { slightly to approximately } 110^{\circ} \mathrm{C} \text {, which confirms the decreasing heat flux in the } \\
\text { combustion zone. Smoke layer was about } 90 \mathrm{~cm} \text { above the floor. }\end{array}$ \\
\hline 720 & 900 & $\begin{array}{l}\text { A significant increase in the intensity of the fire was noticed. The flame reached a } \\
\text { height of } 110 \mathrm{~cm} \text { above the floor. The temperature increased to } 97^{\circ} \mathrm{C} \text {. The smoke } \\
\text { layer increased to a level of approximately } 230 \mathrm{~cm} \text { above the floor. }\end{array}$ \\
\hline 900 & 1200 & $\begin{array}{l}\text { The maximum temperature displayed on a thermal imaging camera was } 340^{\circ} \mathrm{C} \text {. } \\
\text { The whole area of the couch was covered by flame which reached the height of } \\
170 \mathrm{~cm} \text { above the floor. The smoke layer was located at a height of } 240 \mathrm{~cm} \text { above the } \\
\text { floor }\end{array}$ \\
\hline 1200 & 1500 & $\begin{array}{l}\text { The temperature indicated by the thermal imaging camera dropped to } 284^{\circ} \mathrm{C} \text {. } \\
\text { The burning intensity was higher in the front of the couch (in the corner of the room). } \\
\text { The height of the flame reached the ceiling level. Low smoke density was observed. }\end{array}$ \\
\hline 1500 & 1800 & $\begin{array}{l}\text { The temperature increased again to } 325^{\circ} \mathrm{C} \text {. The height of diffusion flame reached } \\
170 \mathrm{~cm} \text { above the floor. In the final phase of the test the flame was } 100 \mathrm{~cm} \text { above floor. } \\
\text { The temperature displayed on the thermal imager decreased to } 223^{\circ} \mathrm{C} \text {. }\end{array}$ \\
\hline
\end{tabular}




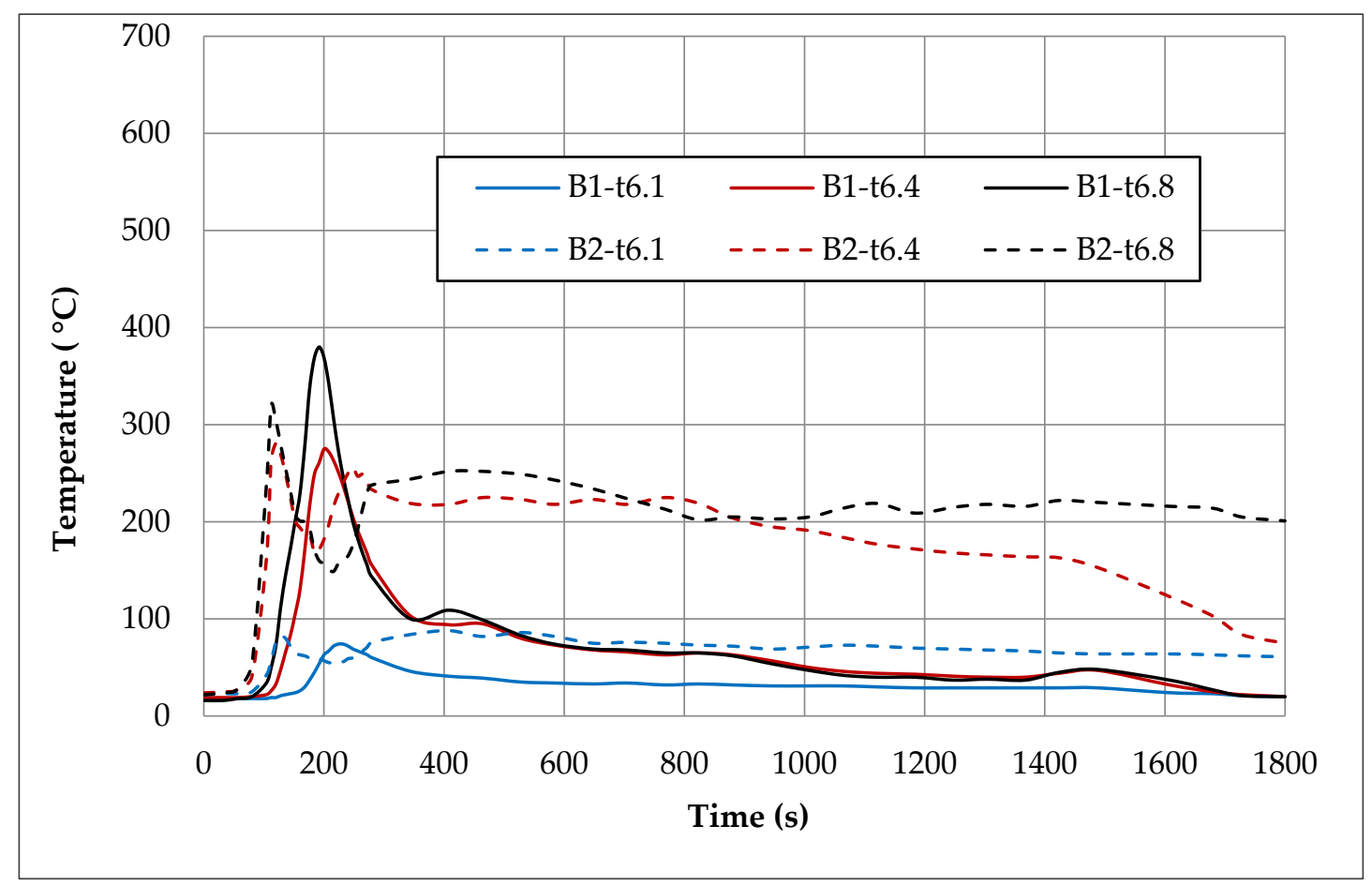

Figure 10. Temperatures measured by thermocouples t6.1, t6.4 and t6.8 during two fire tests B1 and B2.

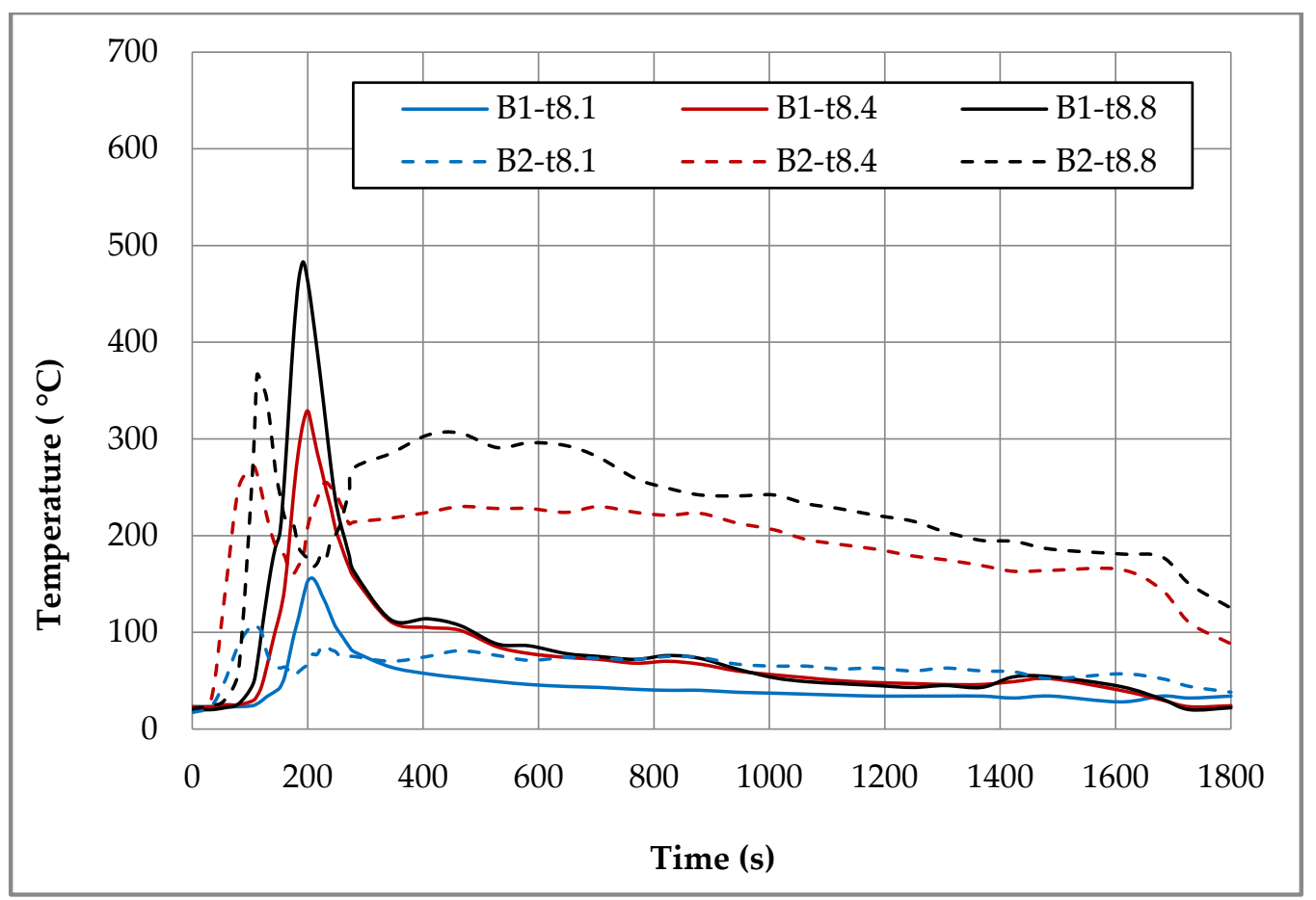

Figure 11. Temperatures measured by thermocouples t8.1, t8.4 and t8.8 during two fire tests B1 and B2. 


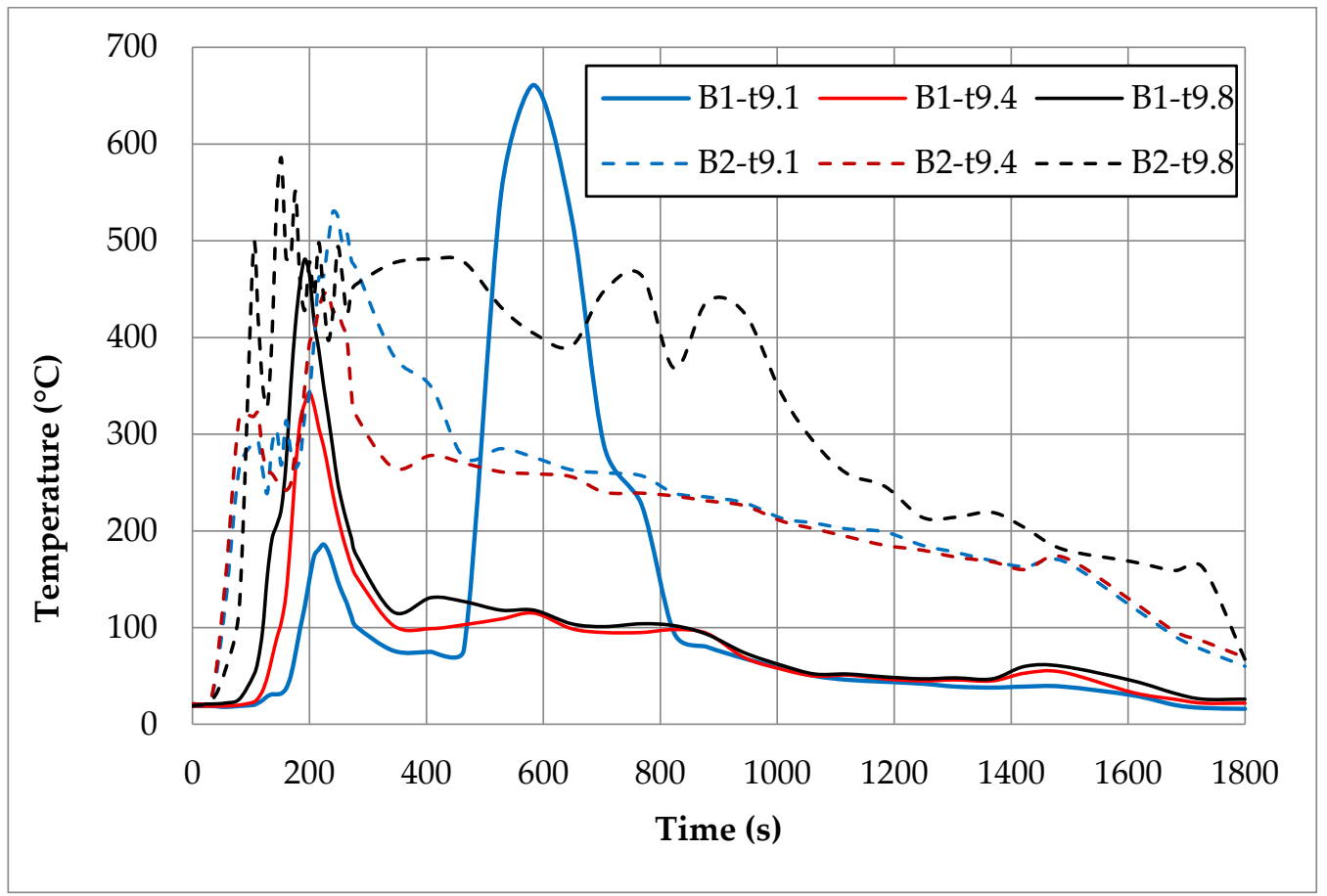

Figure 12. Temperatures measured by thermocouples $\mathrm{t} 9.1, \mathrm{t} 9.4$ and $\mathrm{t} 9.8$ during two fire tests $\mathrm{B} 1$ and $\mathrm{B} 2$.

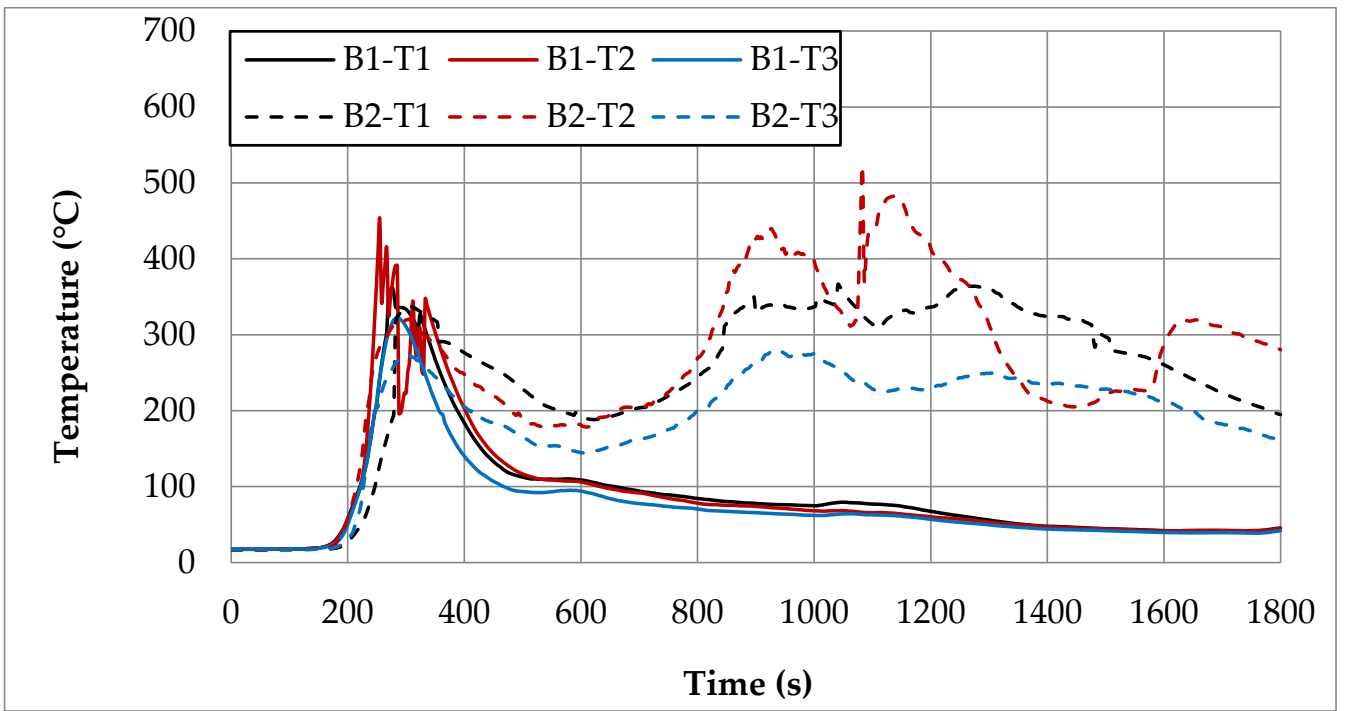

Figure 13. Temperatures measured by thermocouples T1, T2 and T3 during two fire tests B1 and B2.

Table 6. The characteristic parameters of temperature curves registered by thermocouples t6.1, $t 6.4$ and t6.8 during two fire tests B1 and B2.

\begin{tabular}{ccccccc}
\hline \multirow{2}{*}{ Parameters } & \multicolumn{2}{c}{ t6.1 } & \multicolumn{2}{c}{ t6.4 } & \multicolumn{3}{c}{ t6.8 } \\
\cline { 2 - 7 } & B1 & B2 & B1 & B2 & B1 & B2 \\
\hline Maximum $\left({ }^{\circ} \mathrm{C}\right)$ & 74 & 88 & 275 & 281 & 380 & 320 \\
Time to maximum $(\mathrm{s})$ & 224 & 128 & 200 & 128 & 192 & 112 \\
Minimum $\left({ }^{\circ} \mathrm{C}\right)$ & $*$ & 55 & $*$ & 172 & $*$ & 149 \\
Time to minimum $(\mathrm{s})$ & $*$ & 216 & $*$ & 192 & $*$ & 216 \\
\hline
\end{tabular}

* practically no minimum local temperature, because, in the first test, after reaching the maximum, it gradually decreases until the end of the test. 
Table 7. Characteristic parameters of temperature curves registered by thermocouples $\mathrm{t} 8.1, \mathrm{t} 8.4$ and t8.8 during two fire tests B1 and B2.

\begin{tabular}{ccccccc}
\hline \multirow{2}{*}{ Parameters } & \multicolumn{2}{c}{$\mathbf{t 8 . 1}$} & \multicolumn{2}{c}{$\mathbf{t 8 . 4}$} & \multicolumn{3}{c}{ t8.8 } \\
\cline { 2 - 7 } & B1 & B2 & B1 & B2 & B1 & B2 \\
\hline Maximum $\left({ }^{\circ} \mathrm{C}\right)$ & 156 & 108 & 329 & 271 & 483 & 366 \\
Time to maximum $(\mathrm{s})$ & 208 & 104 & 200 & 104 & 192 & 112 \\
Minimum $\left({ }^{\circ} \mathrm{C}\right)$ & $*$ & 55 & $*$ & 161 & $*$ & 171 \\
Time to minimum $(\mathrm{s})$ & $*$ & 176 & $*$ & 176 & $*$ & 216 \\
\hline
\end{tabular}

* practically no minimum local temperature, because, in the first test, after reaching the maximum, it gradually decreases until the end of the test.

Table 8. Characteristic parameters of temperature curves registered by thermocouples $\mathrm{t} 9.1, \mathrm{t} 9.4$ and t9.8 during two fire tests B1 and B2.

\begin{tabular}{ccccccc}
\hline \multirow{2}{*}{ Parameters } & \multicolumn{2}{c}{$\mathbf{t 9 . 1}$} & \multicolumn{2}{c}{$\mathbf{t 9 . 4}$} & \multicolumn{2}{c}{$\mathbf{t 9 . 8}$} \\
\cline { 2 - 7 } & B1 & B2 & B1 & B2 & B1 & B2 \\
\hline Maximum $\left({ }^{\circ} \mathrm{C}\right)$ & $179(661)$ & 530 & 343 & 446 & 481 & 585 \\
Time to maximum $(\mathrm{s})$ & $232(584)$ & 240 & 200 & 232 & 192 & 152 \\
Minimum $\left({ }^{\circ} \mathrm{C}\right)$ & $*(75)$ & 239 & $*$ & 242 & $*$ & 329 \\
Time to minimum $(\mathrm{s})$ & $*(408)$ & 128 & $*$ & 160 & $*$ & 128 \\
\hline
\end{tabular}

* practically no minimum local temperature, because, in the first test, after reaching the maximum, it gradually decreases until the end of the test.

Table 9. Characteristic parameters of temperature curves registered by thermocouples T1, T2 and T3 during two fire tests B1 and B2.

\begin{tabular}{ccccccc}
\hline Parameters & \multicolumn{2}{c}{ T1 } & \multicolumn{2}{c}{ T2 } & \multicolumn{2}{c}{ T3 } \\
\cline { 2 - 7 } & B1 & B2 & B1 & B2 & B1 & B2 \\
\hline Global maximum $\left({ }^{\circ} \mathrm{C}\right)$ & 363 & 366 & 453 & 521 & 323 & 280 \\
Time to global maximum $(\mathrm{s})$ & 276 & 1041 & 255 & 1083 & 285 & 933 \\
The first local maximum $\left({ }^{\circ} \mathrm{C}\right)$ & $* *$ & 337 & $* *$ & 320 & $* *$ & 272 \\
Time to the first local & $* *$ & 306 & $* *$ & 300 & $* *$ & 300 \\
$\quad$ maximum $(\mathrm{s})$ & $*$ & 190 & 196 & 178 & $*$ & 144 \\
Local minimum $\left({ }^{\circ} \mathrm{C}\right)$ & $*$ & 639 & 288 & 609 & $*$ & 609 \\
Time to local minimum $(\mathrm{s})$ & & & & & & $*$
\end{tabular}

* practically no minimum local temperature, because, in the first test, after reaching the maximum, it gradually decreases until the end of the test. ${ }^{* *}$ the first local maximum is also global maximum.

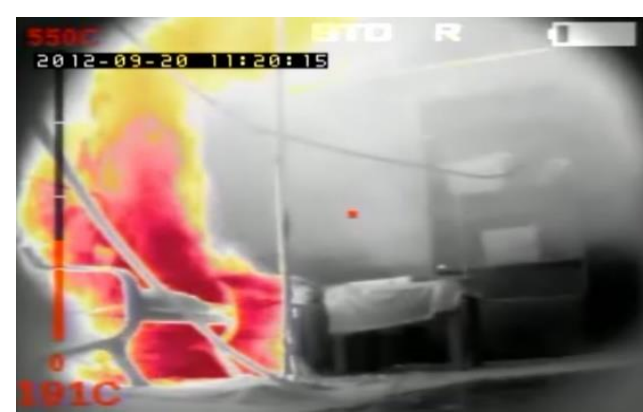

(a)

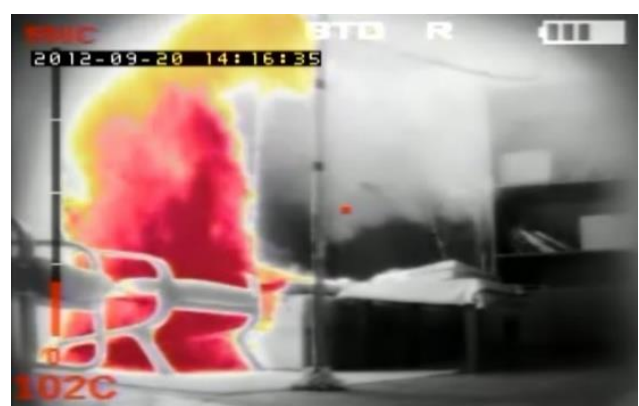

(b)

Figure 14. Frames from the movie recorded with thermal imaging camera at $180 \mathrm{~s}$ of the fire in the: (a) sealed apartment; (b) unsealed apartment. 


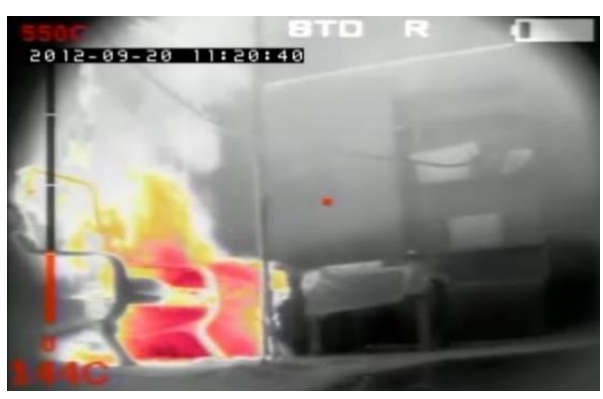

(a)

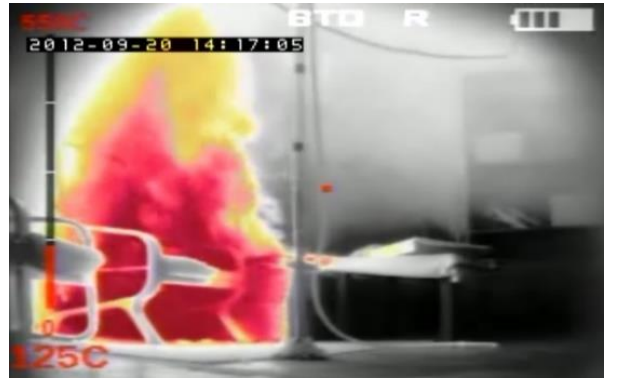

(b)

Figure 15. Frames from the movie recorded with thermal imaging camera at $210 \mathrm{~s}$ of the fire in the: (a) sealed apartment; (b) unsealed apartment.

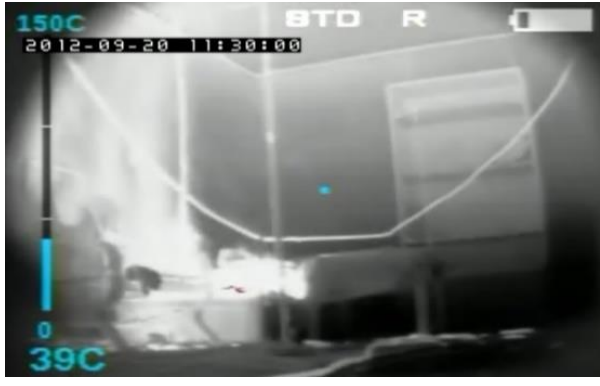

(a)

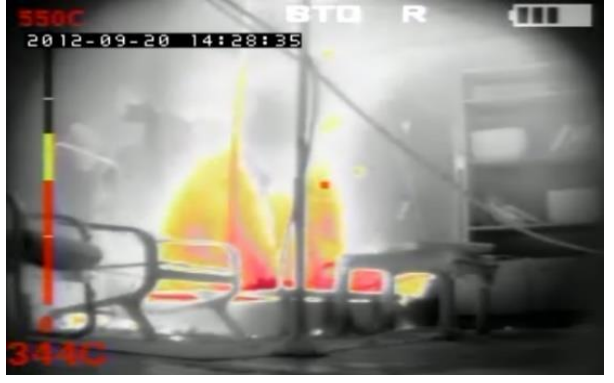

(b)

Figure 16. Frames from the movie recorded with a thermal imaging camera at $900 \mathrm{~s}$ of the fire in the: (a) sealed apartment; (b) unsealed apartment.

Table 10. Values of times after which the temperature measured by thermocouples $t 6.4, \mathrm{t} 8.4$ and $\mathrm{t} 9.4$ reached a critical value of $60^{\circ} \mathrm{C}$ during its growth and drop.

\begin{tabular}{ccccc}
\hline \multirow{2}{*}{ No. of Thermocouple } & \multicolumn{2}{c}{ B1 } & \multicolumn{2}{c}{ B2 } \\
\cline { 2 - 5 } & time 1 (s) & time 2 (s) & time 1 (s) & time 2 (s) \\
\hline $\mathrm{t} 6.4$ & 134 & 880 & 85 & $*\left(84^{\circ} \mathrm{C}\right)$ \\
$\mathrm{t} 8.4$ & 128 & 944 & 95 & $*\left(67^{\circ} \mathrm{C}\right)$ \\
$\mathrm{t} 9.4$ & 134 & 1005 & 87 & $*\left(69^{\circ} \mathrm{C}\right)$ \\
\hline
\end{tabular}

* during the B2 test (unsealed apartment), the temperature at a height of $1.85 \mathrm{~m}$ did not drop below $60^{\circ} \mathrm{C}$ by the end of the test (in brackets the value measured at the end of the test is given).

Table 11. Values of temperature and height of the smoke layer for selected times of fire during two analyzed tests B1 and B2.

\begin{tabular}{|c|c|c|c|c|c|c|c|c|c|c|}
\hline \multirow{3}{*}{ Parameters } & \multicolumn{10}{|c|}{ Time [s] } \\
\hline & \multicolumn{2}{|c|}{180} & \multicolumn{2}{|c|}{210} & \multicolumn{2}{|c|}{360} & \multicolumn{2}{|c|}{540} & \multicolumn{2}{|c|}{720} \\
\hline & B1 & B2 & B1 & B2 & B1 & B2 & B1 & B2 & B1 & B2 \\
\hline Temperature $\left({ }^{\circ} \mathrm{C}\right)$ & 191 & 120 & 144 & 125 & 55 & 98 & 46 & 88 & 38 & 97 \\
\hline Flame height $(\mathrm{cm})$ & 255 & 255 & 150 & 255 & 90 & 130 & 90 & 90 & 90 & 110 \\
\hline Flame length under the ceiling $(\mathrm{cm})$ & 120 & 80 & 0 & 0 & 0 & 0 & 0 & 0 & 0 & 0 \\
\hline Smoke height $(\mathrm{cm})$ & 34 & 130 & 40 & 165 & 50 & 150 & 70 & 210 & 90 & 230 \\
\hline \multirow{2}{*}{ Parameters } & \multicolumn{2}{|c|}{900} & \multicolumn{2}{|c|}{1080} & \multicolumn{2}{|c|}{1260} & \multicolumn{2}{|c|}{1440} & \multicolumn{2}{|c|}{1620} \\
\hline & B1 & B2 & B1 & B2 & B1 & B2 & B1 & B2 & B1 & B2 \\
\hline Temperature $\left({ }^{\circ} \mathrm{C}\right)$ & 38 & 344 & 37 & 218 & 34 & 284 & 32 & 320 & 32 & 405 \\
\hline Flame height $(\mathrm{cm})$ & 70 & 170 & 50 & 130 & 40 & 255 & 40 & 190 & 40 & 255 \\
\hline Flame length under the ceiling $(\mathrm{cm})$ & 0 & 0 & 0 & 0 & 0 & 0 & 0 & 0 & 0 & 80 \\
\hline Smoke height $(\mathrm{cm})$ & 90 & 240 & 90 & 230 & 70 & 240 & 70 & 230 & 70 & 240 \\
\hline
\end{tabular}




\section{Discussion}

The analysis based on the results presented in Chapter 3 can be found in this section. After analyzing the results of the tightness of the residential apartment, it was found that, in the sealed apartment (B1), a lower number of air exchanges of the entire volume of the apartment in one hour was $5.8 \mathrm{~h}^{-1}$, with a difference in internal and external pressure of $50 \mathrm{~Pa}$. In the unsealed apartment the $\mathrm{n}_{50}$ value was $11.6 \mathrm{~h}^{-1}$. These results have an impact on the permeability and air flow as well as the leakage stream in both analyzed apartments. According to (Journal of Laws of 2017, item 2285), air permeability for windows and balcony doors in low, medium-high and high buildings should be at a pressure of $100 \mathrm{~Pa}$, not more than $2.25 \mathrm{~m}^{3} /(\mathrm{m} \cdot \mathrm{h})$ in relation to up to the contact line length or $9 \mathrm{~m}^{3} /\left(\mathrm{m} \cdot \mathrm{h}^{2}\right)$ in relation to the surface area. In the case of a new window installed in the sealed apartment, the air permeability was $5.7 \mathrm{~m} /\left(\mathrm{h} \cdot \mathrm{m}^{2}\right)$, while in the unsealed one this value exceeded $9 \mathrm{~m} /\left(\mathrm{m} \cdot \mathrm{h}^{2}\right)$ and amounted to $11.3 \mathrm{~m}^{3} /\left(\mathrm{m} \cdot \mathrm{h}^{2}\right)$. Research using the Blower Door device showed that the unsealed apartment had lower air tightness (higher unit leakage flow), and the $V_{50}$ air flow was twice as large as in the sealed one. According to the regulation, the number of air changes per hour for buildings with gravitational ventilation should be $n_{50} \leq 3 \mathrm{~h}^{-1}$. Therefore, after performing a leak test of both residential apartments by the Blower Door method, it was decided to open one window sash during the second fire test (B2). The reason for this was, among others, the failure of the sealed apartment to meet the assumed leakage test at the level of $\mathrm{n}_{50} \leq 3 \mathrm{~h}^{-1}$.

During the test in a sealed room (B1), after approximately $120 \mathrm{~s}$ after ignition, the pressure in the room began to increase, reaching after $196 \mathrm{~s}$ the maximum overpressure value of $134 \mathrm{~Pa}$. The pressure then dropped sharply to reach atmospheric pressure after approximately $240 \mathrm{~s}$. From this moment, a slight increase in underpressure can be observed in the room, which after a time of about $276 \mathrm{~s}$ reaches its maximum value of $-12.4 \mathrm{~Pa}$. From this moment, the pressure gradually increases to approach the level of atmospheric pressure after about $400 \mathrm{~s}$.

During the test in the unsealed apartment (B2), the overpressure began to increase almost from the very beginning to reach a maximum value of $4.8 \mathrm{~Pa}$ after approximately $69 \mathrm{~s}$ (about $130 \mathrm{~Pa}$ less than in the case of the sealed apartment). At the moment, it decreased slightly. Strong oscillations of overpressure between values of 0.4 and $2.8 \mathrm{~Pa}$ can be observed after approximately $150 \mathrm{~s}$ (not including a single peak of $4.4 \mathrm{~Pa}$ at the $363 \mathrm{~s}$ of the test).

The pressure measurement results obtained during the experiments were a big surprise due to the fact that the apartments were not completed in accordance with the number of air changes per hour $\left(\mathrm{n} 50 \leq 3 \mathrm{~h}^{-1}\right)$ assumed in technical conditions for buildings with gravity ventilation [2].

Due to large differences in the development of the fire during both tests, the analysis of the results obtained was divided into three stages. The first of them analyzed the fire in a sealed apartment, the second in the unsealed one and the third compared the results of both tests B1 and B2.

\subsection{Fire in the Sealed Apartment (B1)}

Two armchairs and the top layer of the couch, which was made from polyurethane foam, were burned out during the B1 test in a sealed apartment. Due to the lack of a sufficiently high temperature, flashover phenomena were not observed. Because of insufficient oxygen, the quenching phase began after just $200 \mathrm{~s}$ of fire. Based on the image from the Hornet thermal imaging camera, it can be stated that after only about $20 \mathrm{~min}$ the fire was limited to small individual flames appearing on the surface of the couch. The highest intensity of the developed fire was observed after about $170 \mathrm{~s}$ of its duration, when the flames reached the ceiling and their length along it was about $120 \mathrm{~cm}$ (see Table 11). After about $180 \mathrm{~s}$, the fire passed from the fuel-controlled stage to the ventilation-controlled stage. Moreover, due to the release of a large amount of smoke (insufficient oxygen leads to incomplete combustion), the level of the smoke layer already after approximately $180 \mathrm{~s}$ reached the level of $34 \mathrm{~cm}$ (calculated from the floor), which then increased, remaining until the end of the test at a height of $70-90 \mathrm{~cm}$. This situation is very dangerous from the point of view of evacuation due to moving in an environment with high toxicity and low visibility range. Based on the temperature characteristics 
shown in the Figures 10-13 and the characteristic values summarized in Tables 6-9 regarding the B1 test in a sealed apartment, it can be concluded that they were of the same nature at all measured points. It consisted in the fact that after about $100 \mathrm{~s}$ from the moment of ignition (which the thermocouple was located lower the later) the temperature began to increase rapidly, reaching its maximum after about $200 \mathrm{~s}$ of the fire. The exception here was the local increase in temperature to over $600{ }^{\circ} \mathrm{C}$ after about $600 \mathrm{~s}$ from the moment of ignition measured by the thermocouple 19.1 caused by the flame coming from the burning couch. Therefore, it was not included in the further analysis. The highest maximum values of around $480{ }^{\circ} \mathrm{C}$ were measured in the ceiling zone $(245 \mathrm{~cm})$ by $t 8.8$ and $t 9.8$ thermocouples mounted near the ignition source (see Figure 6). The maximum temperature measured by thermocouple t6. 8 placed at the same height in the corner of the room was about $100{ }^{\circ} \mathrm{C}$ lower. As expected, lower maximum temperatures were obtained at lower altitudes. For example, at a height of $185 \mathrm{~cm}$, these differences ranged from approximately $100{ }^{\circ} \mathrm{C}$ (for the t6 tree) to approximately $160^{\circ} \mathrm{C}$ (for the t8 tree) and at a height of $105 \mathrm{~cm}$ from approximately $300^{\circ} \mathrm{C}$ (for the t6 tree) to approximately $330{ }^{\circ} \mathrm{C}$ (for the t8 tree). Among the single thermocouples T1, T2 and T3, the highest temperature exceeding $450{ }^{\circ} \mathrm{C}$ was indicated by the thermocouple $\mathrm{T} 2$ placed above the couch and the lowest equal to approximately $320{ }^{\circ} \mathrm{C}$ by thermocouple T3 placed opposite the chair. These values were reached about $70 \mathrm{~s}$ later compared to the maxima on the other thermocouples. This is due to the movement of the combustion zone from the armchairs to the couch. In addition, between $270 \mathrm{~s}$ and $330 \mathrm{~s}$ on the T2 thermocouple, strong and rapid temperature fluctuations can be observed (not found on any other thermocouple) in the range from 200 to $450^{\circ} \mathrm{C}$ related to the intense burning of polyurethane foam on the couch mattress. After time when maximum was reached, due to the insufficient amount of oxygen, the fire entered the quenching phase, which resulted in a gradual decrease in temperature. After approximately $400 \mathrm{~s}$ from ignition, a smoke height was more than $180 \mathrm{~cm}$ and a value of temperature was about $100{ }^{\circ} \mathrm{C}$ (at lower altitudes it was several dozen degrees lower). To a level equal to $60^{\circ} \mathrm{C}$ accepted as safe for humans at this altitude, the temperature decreased after approximately $1000 \mathrm{~s}$ from the moment of ignition.

\subsection{Fire in the Unsealed Apartment (B2)}

During the B2 test in an unsealed apartment, two armchairs and the couch were completely burned out. Because of a too low fire load density, no flashover phenomena were observed. Starting from $50 \mathrm{~s}$, a systematic increase in flame begins, which after $90 \mathrm{~s}$ reached a height of $110 \mathrm{~cm}$ (calculated from the floor). After about $120 \mathrm{~s}$, the convection column quickly reached the ceiling. After $150 \mathrm{~s}$, the flame spread to the couch. After about $180 \mathrm{~s}$, its rapid spread throughout the couch was recorded, with the flame height reaching ceiling, breaking down along it for a length of about $80 \mathrm{~cm}$. The smoke layer then reached the level of $130 \mathrm{~cm}$ above the floor. In the range of 210-300 s, the smoke layer was the lowest equal to approximately $90 \mathrm{~cm}$. This situation at this time practically prevents the evacuation process. Later, it began to gradually increase, reaching a height of approximately $230 \mathrm{~cm}$ after $720 \mathrm{~s}$. Combustion intensity dropped after about $300 \mathrm{~s}$, which affected the temperature and flame height drop. Due to the transition of the couch-burning process, which is a significant fire load, to the developed phase, starting from $600 \mathrm{~s}$, the intensity of combustion begins to increase again, reaching its maximum in the range of 900-1200 s. This resulted in a significant increase in temperature and flame height. Practically until the end of the test, which lasted $30 \mathrm{~min}$, the fire was not extinguished, as evidenced by the relatively high temperature and current flame indicated by the thermal imaging camera. Due to the sufficient amount of oxygen, fire is fuel-controlled during the whole test.

During the B2 test in the unsealed room, approximately $70 \mathrm{~s}$ after ignition, a fast temperature rise to the maximum begins. The time to reach this temperature depends on the location of the measuring point and the shortest equal to $104 \mathrm{~s}$ is for thermocouples t8.4 $(185 \mathrm{~cm})$ and $t 8.1(105 \mathrm{~cm})$, which are the closest to the source of the fire. For thermocouples mounted at the same heights on the t 6 thermocouple tree (in the corner), these times are slightly longer and amount to about $128 \mathrm{~s}$. The highest maximum temperature values at all analyzed levels were measured by thermocouples mounted on a 9 tree located by the wall behind the couch. At a height of $245 \mathrm{~cm}$, it reached the value of $585^{\circ} \mathrm{C}$, while 
on other thermocouples mounted at the same height it did not exceed $400{ }^{\circ} \mathrm{C}\left(366^{\circ} \mathrm{C}\right.$ on 18.8 and $320^{\circ} \mathrm{C}$ on t6.8). Temperature curves are irregular, consisting in the fact that after reaching the first maximum, the temperature drops momentarily and then increases again to a value that is lower than the previous one in the case of thermocouples $t 6$ and $t 8$, whereas, in the case of the $t 9$ tree and individual thermocouples, T1-T3 is higher. On the 19 tree closest to the couch in the time interval of 100-250 s, significant and relatively fast temperature fluctuations can be observed, which at a height of $245 \mathrm{~cm}$ reach up to $250 \mathrm{~cm}$. When it comes to single thermocouples, the highest temperature of $521^{\circ} \mathrm{C}$ was recorded on the thermocouple T2 located above the couch. It took place in the range of 900-1100 s, when its combustion was the most intense. At the same time, maximum temperature values were recorded on thermocouples $\mathrm{T} 1$ and $\mathrm{T} 3$. Until the end of the test, the temperatures they measured did not fall below $150{ }^{\circ} \mathrm{C}$. A high temperature of about $200{ }^{\circ} \mathrm{C}$ was also maintained in the ceiling zone in the corner of the room (thermocouple t6.8).

\subsection{Comparison of both Tests B1 and B2}

To compare the two fire tests in the sealed and unsealed apartment, several criteria have been adopted that both characterize the fire itself and affect the degree of danger to people in the apartment. These are: the duration of the fire and its intensity, the height of the flame and its changes in time, the location of the smoke zone, the nature of the temperature changes and its maximum values in the ceiling zone and at the height over a man's head as well as its value in final phase of the test.

During both tests, the fire was located and did not ignite in the whole fire zone. The fire load density at which the tested materials were collected $\left(9 \mathrm{~m}^{2}\right.$ floor area) was $306.4 \mathrm{MJ} / \mathrm{m}^{2}$. In contrast, the fire load density for the total floor area was $178.9 \mathrm{MJ} / \mathrm{m}^{2}$ for $15.41 \mathrm{~m}^{2}$ of the fire room area.

As expected, due to the sufficient amount of oxygen, the fire in the unsealed apartment (B2) was much more intense than in the sealed one (B1). In this case, it was controlled by the fuel throughout the test, while in the sealed apartment after about $180 \mathrm{~s}$ it went into the phase controlled by ventilation. Higher intensity affected the flame size. In the case of the sealed apartment, it reached the ceiling only at the beginning of the test. After about $200 \mathrm{~s}$, it began to gradually decrease. In the final phase, only single flames were visible up to a height of $40 \mathrm{~cm}$. During the test in the unsealed apartment, the flame reached the ceiling in the initial phase of the fire lasting up to about $200 \mathrm{~s}$. Then it fell down and its height varied between $70 \mathrm{~cm}$ and $90 \mathrm{~cm}$. After approximately $1100 \mathrm{~s}$ the flame from the burning couch reached the ceiling again. After about $1620 \mathrm{~s}$ of fire, its length along the ceiling was about the width of the couch. Throughout the test, the smoke layer in the sealed apartment was located much lower than in the unsealed apartment. After about $180 \mathrm{~s}$, it reached the lowest position of $34 \mathrm{~cm}$ (calculated from the floor), after which it rose a bit by turning around 70-90 cm. In the unsealed apartment, about $180 \mathrm{~s}$ after ignition, it dropped to the level of $130 \mathrm{~cm}$, to continue to remain at a safe level for humans $(230-240 \mathrm{~cm})$ until the end of the test.

Due to significant differences in the combustion process resulting primarily from a much larger amount of available oxygen during tests in the unsealed apartment, significantly different temperature characteristics were observed for both analyzed apartment. In the case of the sealed apartment, after reaching the maximum, it first decreases quickly to a level of about $100{ }^{\circ} \mathrm{C}$ and then it slows down much slower until the end of the test with a slight fluctuation around $400 \mathrm{~s}$ related to the transition of the flame to the couch and the combustion of its top layer. In the case of the unsealed apartment, when the temperature reaches the first maximum, a sharp decrease can be observed, but only to a value that was not lower than $150^{\circ} \mathrm{C}$, and then a further increase associated with the transition to the phase in which the entire couch is burning. This causes a high temperature to remain (at a height of $245 \mathrm{~cm}$ it ranges between $200-300^{\circ} \mathrm{C}$ ) for a long time. Only with the beginning of the phase quenching after a period of about $800-1000 \mathrm{~s}$ after ignition (it depends on the location of the measuring point) does it begin to gradually decrease in temperature. Comparing the maximum temperatures recorded in the ceiling zone with each other, it can be stated that the values measured on the trees $t 8$ (between the fireplace with the source of fire and the couch), $t 6$ (in the corner of the room) and the single thermocouple T3 
(opposite the armchair) were higher by about $40-80{ }^{\circ} \mathrm{C}$ for the sealed apartment. The opposite was true for the $\mathrm{t} 9$ tree behind the couch. The temperature measured by thermocouple $\mathrm{t} 9.8$ was about $100{ }^{\circ} \mathrm{C}$ higher in the unsealed apartment. As for the thermocouple T1 (furthest from the combustion zone), the maximum temperatures were comparable in both examined cases. In turn, the maximum temperature measured by the thermocouple T2 placed above the couch was higher by about $70{ }^{\circ} \mathrm{C}$ during the test in the unsealed apartment. It was achieved only in the third phase when burning the couch (after about $1083 \mathrm{~s}$ ). During the test in a sealed apartment after about $1200 \mathrm{~s}$, the temperature at all analyzed measuring points dropped to a level $60{ }^{\circ} \mathrm{C}$ safe for humans. However, during the test in the unsealed apartment, the temperature value was measured at practically all measuring points (except for the lowest located at a height of $105 \mathrm{~cm}$ ) and exceeded this value.

The uncertainty in determining the parameters of the fire environment resulted not only from the limited accuracy of instruments and measurement methods, but above all from the stochastic nature of the phenomenon that is fire. This is also associated with the fact that it is virtually impossible to provide the same conditions for the development of fire in both apartments differing only in the degree of air tightness. The uncertainty of results was also caused by the difference between the wind speed blowing during the test in sealed $(1.5 \mathrm{~m} / \mathrm{s})$ and unsealed $(4.5 \mathrm{~m} / \mathrm{s})$ apartments. Assuming that the windows in both apartments were located on the north side, this could affect the maintaining of higher temperatures in the unsealed apartment for a longer period and hence faster burning of furniture. The influence of cool air and wind on the direction and intensity of fire in the unsealed apartment was also visible on the T3 thermocouple ( $150 \mathrm{~cm}$ from the floor by the chair), because the highest temperature at this point was obtained in the sealed apartment. In addition, a small number of fire tests have an impact on the accuracy of the results obtained. It resulted from technical problems and limited financial and personal resources.

\section{Conclusions}

On the basis of the analysis of results obtained during full-scale fires included in Chapter 5 , the following final conclusions have been formulated:

1. Taking into account the intensity of the fire and its duration, which had a significant effect on maintaining a high temperature in the room for a longer time, a greater threat to humans, mainly due to the effects of thermal radiation, is a fire in the unsealed apartment. In the case of the sealed apartment due to the limited amount of oxygen, after about $900 \mathrm{~s}$ its intensity decreased so that the height of individual flames above the couch did not exceed $40 \mathrm{~cm}$ and the temperature at a height of $185 \mathrm{~cm}$ fell below $80^{\circ} \mathrm{C}$ (during the whole test the seats and only the upper part of the couch burned out). At the same time, in the sealed apartment, the developed combustion phase of the couch began, during which the height of the flames reached the ceiling and the temperature near the couch practically remained at the level of $200{ }^{\circ} \mathrm{C}$ until the end of the test.

2. Considering the location of the smoke layer due to its significantly lower height above the floor (in the initial phase of the fire in a sealed room it even dropped to $34 \mathrm{~cm}$, then increased slightly, but practically remained at a level not higher than $70 \mathrm{~cm}$ until the end of the test), due to the toxicity of the products contained in the smoke (especially carbon monoxide emitted during incomplete combustion), a reduction in oxygen concentration and visibility range, a fire in the sealed apartment is a greater threat to humans. Moreover, in this situation, there is a greater probability of a possible backdraft phenomenon, for example, in the case of a supply of oxygen as a result of opening the apartment door by fireman or cracking the glass due to its heating up to a temperature exceeding $300^{\circ} \mathrm{C}$. In the unsealed apartment, the lowest location of the smoke layer in the initial phase of the test was nearly $130 \mathrm{~cm}$, while starting from about $600 \mathrm{~s}$ it remained at a safe height for people (more than $200 \mathrm{~cm}$ ).

3. Due to a much larger amount of oxygen in the unsealed apartment (test B2), measured temperatures were significantly different from that obtained in the test B1 (sealed apartment). In the first case (B1), due to a lack of sufficient oxygen, the fire lasted much for less time and was limited to only 
burning the armchair and its immediate surroundings. This is demonstrated by the temperature curve containing only one maximum. When it was reached, the temperature continued to decrease until the end of the test. In the case of apartment unsealed, there were a few local temperature maxima. It resulted, among others from the fact that in addition to the armchair, the fire switched to the couch, which resulted in the further phase of the fire (in the range from 900 to $1500 \mathrm{~s}$ ) again more intense heat release resulting in a re-increase in temperature.

4. The maximum temperature values recorded, except for one case when the t9 thermocouple was in direct flame range, did not exceed $600{ }^{\circ} \mathrm{C}$. The highest temperatures exceeding $450{ }^{\circ} \mathrm{C}$ were measured by thermocouples mounted on the $t 9$ tree closest to the original source of fire. In this case, they were higher in the test B2 (apartment unsealed). As for the remaining thermocouple trees, higher maximum temperatures were most often obtained during the test B1 (sealed apartment). The temperature measured at a height of $185 \mathrm{~cm}$ (above the head of a standing man of average height) after about $80 \mathrm{~s}$ (less than $1.5 \mathrm{~min}$ ) in the case of the unsealed apartment and $120 \mathrm{~s}(2 \mathrm{~min})$ in the case of the sealed apartment exceeded the value constituting a threat to health and life human (assumed to be $60^{\circ} \mathrm{C}$ ). At a height of $105 \mathrm{~cm}$ (man in an inclined position), this time was slightly longer and in the worst case it was $90 \mathrm{~s}$ (thermocouple 19.1 during test B2) and in the best $200 \mathrm{~s}$ (thermocouple t6.1 during test B1).

5. From the point of view of human safety, exceeding the critical value of $60^{\circ} \mathrm{C}$ at a height $1.85 \mathrm{~m}$ occurred the fastest (after about $85 \mathrm{~s}$ ) in the case of test B2 (unsealed apartment), and the latest (after about $134 \mathrm{~s}$ ) in the case of test B1 (sealed apartment). Differences between times depending on the location of the thermocouple tree did not exceed $10 \mathrm{~s}$. A temperature drop to the level of $60{ }^{\circ} \mathrm{C}$ in the quenching phase was observed only in the case of the B1 test in a sealed apartment. In the $\mathrm{B} 2$ test, they were above the critical value until the end of the measurements. The fastest decrease occurred in the case of the $t 6$ tree placed in the corner of the room and at the latest in the case of the $\mathrm{t} 9$ tree located behind the couch.

The temperature curves obtained as a result of full-scale fire tests can be used to estimate the heat release rate (HRR curves) using the known inverse method, e.g., the one given in [24]. In addition, they can be useful when validating either a computer zone or field fire model. The above-mentioned issues will be the subject of another article related to conducted fire experiments.

Author Contributions: Conceptualization, D.S.; methodology, J.G. and D.S.; introduction, J.G and D.S.; formal analysis, J.G and D.S..; investigation, D.S.; resources, J.G.; data curation, J.G. and D.S.; writing-original draft preparation, J.G. and D.S.; writing-review and editing, J.G.; visualization, J.G. and D.S.; supervision, J.G.; project administration, D.S.; funding acquisition, D.S. All authors have read and agreed to the published version of the manuscript.

Funding: Research on the heat release rate (HRR) according to the ISO 9705 method, were financed from a scholarship as part of the project "Scholarships as an opportunity for the development of the Silesia Voivodeship", co-financed by the European Union under the European Social Fund.

Acknowledgments: To the Building Research Institute in Warsaw and the Smay Group from Cracow for help in the conducting tests, especially in the field of temperature and pressure measurement.

Conflicts of Interest: The authors declare no conflict of interest.

\section{References}

1. Gałaj, J.; Saleta, D. Impact of Apartment Tightness on the Concentrations of Toxic Gases Emitted During a Fire. Sustainability 2020, 12, 223. [CrossRef]

2. Regulation of the Minister of Infrastructure and Construction of November 14, 2017 Regarding the Technical Conditions to be Met by Buildings and Their Location; Journal of Laws 2017, Item 2285; Chancellery of the Prime Minister of Poland: Warsaw, Poland, 2017; Volume Dz.U. 2017.2285.

3. Kosiorek, M. Fire Impacts on Users and Construction. In Fire Protection, Part. 1; Builder: Warsaw, Poland, 2015; pp. 86-90. 
4. $\quad$ Back, A. Fire Development in Insulated Compartments: Effects from Improved Thermal Insulation; Brandteknik och Riskhantering, Lunds Tekniska Högskola Lunds Universitet: Lund, Sweden, 2012.

5. Kerber, S. Impact of Ventilation on Fire Behavior in Legacy and Contemporary Residential Construction; Department of Homeland Security, Underwriters Laboratories: Northbrook, IL, USA, 2010.

6. Saleta, D. Fire Observation. In Fire Review, 7th ed.; KG PSP: Warsaw, Poland, 2013; pp. 16-19.

7. Kokot-Góra, S. Theory of Combustion and Fire-The Latest Research and Old Truths, Part III in Action; Elamed: Katowice, Poland, 2017; pp. 14-20.

8. Abecassis-Empis, C.; Reszka, P.; Steinhaus, T.; Cowlard, A.; Biteau, H.; Welch, S.; Rein, G.; Torero, J.L. Characterisation of Dalmarnock Fire Test One. Exp. Therm. Fluid Sci. 2008, 32, 1334-1343. [CrossRef]

9. Rein, G.; Torero, J.; Jahn, W.; Stern-Gottfried, J.; Ryder, N.L.; Desanghere, S.; Lazaro, M.; Mowrer, F.; Coles, A.; Joyeux, D.; et al. Round Robin Study of a priori Modelling Prediction of The Dalmarnock Fire Test One. Fire Saf. J. 2009, 44, 590-602. [CrossRef]

10. Rein, G.; Jahn, W.; Torero, J.L. Modelling of Growth Phase of Dalarnock Fire Test One. In Proceedings of the 12th International Fire and Materials Conference, San Francisco, CA, USA, 31 January-2 February 2011.

11. Guillaume, E.; Didieux, F.; Thiry, A.; Bellivier, A. Real-scale fire tests of one bedroom apartments with regard to tenability assessment. Fire Saf. J. 2014, 70, 81-97. [CrossRef]

12. Walton, W.D.; Thomas, P.H.; Ohmiya, Y. Estimating Temperatures in Compartment Fires. In SFPE Handbook of Fire Protection Engineering, 5th ed.; Springer: New York, NY, USA, 2016; pp. 996-1023.

13. Vinha, J.; Manelius, E.; Korpi, M.; Salminen, K.; Kurnitski, J.; Kiviste, M.; Laukkarinen, A. Airtightness of residential buildings in Finland. Build. Environ. 2015, 93, 128-140. [CrossRef]

14. Janardhan, R.K.; Hostikka, S. Experiments and Numerical Simulations of Pressure Effects in Apartment Fires. Fire Technol. 2017, 53, 1353-1377. [CrossRef]

15. Audouin, L.; Rigollet, L.; Prétrel, H.; Le Saux, W.; Röwekamp, M. OECD PRISME project: Fires in confined and ventilated nuclear-type multi-compartments-Overview and main experimental results. Fire Saf. J. 2013, 62, 80-101. [CrossRef]

16. Prétrel, H.; Le Saux, W.; Audouin, L. Pressure variations induced by a pool fire in a well-confined and force-ventilated compartment. Fire Saf. J. 2012, 52, 11-24. [CrossRef]

17. Brohez, S.; Caravita, I. Overpressure induced by fires in airtight buildings. J. Phys. Conf. Ser. 2018, 1107, 042031. [CrossRef]

18. Caravita, I. Fire Development in Passive Houses: Experimental Analysis and Validation of Theoretical Models. Master's Thesis, University of Bologna, Bologna, Italy, March 2018.

19. Available online: http://www.firemax.pl/uploads/files/Hornet_160_320_MXpdf06011.pdf/2018-09-05 (accessed on 10 January 2020).

20. Available online: https://www.draeger.com/Library/Content/9094741_ucf_7000_pi_pl.pdf/2018-09-05 (accessed on 15 February 2020).

21. Available online: http://www.kompartpomiar.pl/?page=produkt\&id=123 (accessed on 3 September 2018).

22. Erhorn-Kluttig, H.; Lahmidi, H. Airtightness Requirements for High Performance Building Envelopes; ASIEPI European Project, Report P157; European Commission: Brussels, Belgium, 2009.

23. Hurley, M.J.; Gottuk, D.T.; Hall, J.R., Jr.; Harada, K.; Kuligowski, E.D.; Puchovsky, M.; Torero, J.L.; Watts, J.M., Jr.; Wieczorek, C.J. SFPE Handbook of Fire Protection Engineering, 5th ed.; National Fire Protection Association: Quincy, MA, USA, 2016.

24. Liu, J.; Chen, M. A simplified Method to Predict the Heat Release Rate of Industrial Nitrocellulose Materials. Appl. Sci. 2018, 8, 910. [CrossRef]

(C) 2020 by the authors. Licensee MDPI, Basel, Switzerland. This article is an open access article distributed under the terms and conditions of the Creative Commons Attribution (CC BY) license (http://creativecommons.org/licenses/by/4.0/). 